\title{
Are the effects of vegetation and soil changes as important as climate change impacts on hydrological processes?
}

\author{
Kabir Rasouli ${ }^{1,2}$, John W. Pomeroy ${ }^{2}$, and Paul H. Whitfield ${ }^{2,3}$ \\ ${ }^{1}$ Department of Geoscience, University of Calgary, Calgary, AB, T2N 1N4, Canada \\ ${ }^{2}$ Centre for Hydrology, University of Saskatchewan, Saskatoon, SK \& Canmore, AB, T1W 3G1, Canada \\ ${ }^{3}$ Environment and Climate Change Canada, Vancouver, BC, V6C 3S5, Canada
}

Correspondence: Kabir Rasouli (kabir.rasouli@usask.ca)

Received: 1 May 2019 - Discussion started: 20 May 2019

Revised: 17 October 2019 - Accepted: 5 November 2019 - Published: 3 December 2019

\begin{abstract}
Hydrological processes are widely understood to be sensitive to changes in climate, but the effects of concomitant changes in vegetation and soils have seldom been considered in snow-dominated mountain basins. The response of mountain hydrology to vegetation/soil changes in the present and a future climate was modeled in three snowmelt-dominated mountain basins in the North American Cordillera. The models developed for each basin using the Cold Regions Hydrological Modeling platform employed current and expected changes to vegetation and soil parameters and were driven with recent and perturbed highaltitude meteorological observations. Monthly perturbations were calculated using the differences in outputs between the present- and a future-climate scenario from 11 regional climate models. In the three basins, future climate change alone decreased the modeled peak snow water equivalent (SWE) by $11 \%-47 \%$ and increased the modeled evapotranspiration by $14 \%-20 \%$. However, including future changes in vegetation and soil for each basin changed or reversed these climate change outcomes. In Wolf Creek in the Yukon Territory, Canada, a statistically insignificant increase in SWE due to vegetation increase in the alpine zone was found to offset the statistically significant decrease in SWE due to climate change. In Marmot Creek in the Canadian Rockies, the increase in annual runoff due to the combined effect of soil and climate change was statistically significant, whereas their individual effects were not. In the relatively warmer Reynolds Mountain in Idaho, USA, vegetation change alone decreased the annual runoff volume by $8 \%$, but changes in soil, climate, or both did not affect runoff. At high elevations in Wolf and Marmot creeks, the model results indicated that vegeta-
\end{abstract}

tion/soil changes moderated the impact of climate change on peak SWE, the timing of peak SWE, evapotranspiration, and the annual runoff volume. However, at medium elevations, these changes intensified the impact of climate change, further decreasing peak SWE and sublimation. The hydrological impacts of changes in climate, vegetation, and soil in mountain environments were similar in magnitude but not consistent in direction for all biomes; in some combinations, this resulted in enhanced impacts at lower elevations and latitudes and moderated impacts at higher elevations and latitudes.

\section{Introduction}

Under warmer, less snowy climates, vegetation and soil properties are expected to change, which will result in evapotranspiration increases (Beniston, 2003) and shifts in runoff patterns (Neilson and Marks, 1994). Vegetation response to warming varies with climate (Stow et al., 2004). Deforestation, afforestation, and disturbance to the vegetation composition are other mechanisms that have widely changed the vegetation cover, especially in mountainous environments. Bosch and Hewlett (1982) reviewed the impacts of deforestation and afforestation on water yield in forested landscapes and concluded that water yield increases in coniferous forests (e.g., pine), deciduous hardwood forests, and shrubs with a reduction in cover. Studies have also shown that the growth rates of trees have increased (Innes, 1991), the forest composition (e.g., in the Pacific Northwest) has changed (Dale and Franklin, 1989), and the treeline has moved vertically and northward in the last century (Hansell et al., 1971). The 
major drivers of vegetation change in western North America are climate, mountain pine beetle, logging, and wildfires (Macias-Fauria and Johnson, 2009; Halofsky et al., 2018).

At northern latitudes, where the air temperature is low, the growing season is short, cloud cover is persistent, and the solar angle is small, the vegetation composition responds quickly to changes in climate and nutrient availability; with warming, rapid changes in thawing and freezing processes (Zhang et al., 2008; Walvoord and Kurylyk, 2016), snowmelt rates, and soil moisture (Bales et al., 2011) are expected. One example of how the interaction between climate and vegetation can change ecosystems is the expansion of shrubs in northern latitudes (Martin et al., 2017; Myers-Smith and Hik, 2018). Warming degrades permafrost in northern mountains and leads to shrub tundra expansion (Tape et al., 2006; Hallinger et al., 2010). Increased shrub coverage traps more windblown snow, increases snowmelt volumes, lowers spring albedo, and alters melt rates (Pomeroy et al., 2006; Krogh and Pomeroy, 2018). Warming has also resulted in increases in the height of the tundra community (Bjorkman et al., 2018). Many mountain plants begin growth at near-freezing temperatures when snowpacks start to melt (Billings and Bliss, 1959), and snow depth and snowmelt rates affect vegetation composition (Billings and Bliss, 1959; Stanton et al., 1994). In a warmer climate, the abundance of coldadapted species decreases and warmth-demanding vegetation expands into higher elevations (Lamprecht et al., 2018); thus, plant communities shift to more northern latitudes (Alberta Natural Regions Committee, 2006; Schneider et al., 2009; Mann et al., 2012; Schneider, 2013; Myers-Smith and Hik, 2018).

Changes in vegetation can lead to changes in soil properties and important local and global feedbacks in ecohydrological processes and energy budgets (Osterkamp et al., 2009; Rawlins et al., 2009). Soil development, however, may not occur as quickly as vegetation change (Innes, 1991), and soil properties may vary from the initial phase of the colonization of the bare surface to the establishment of a forest (Crocker and Major, 1955). In cold regions in general, and mountains in particular, the amount and timing of snowmelt affects vegetation type, soil moisture, nutrient transport, soil and leaf temperature, surface microclimate, and growing season (Billings and Bliss, 1959; Walker et al., 1993; Stanton et al., 1994; Callaghan et al., 2011). Potential changes in soil, especially changes in the organic matter content, can have just as important effects on soil moisture, permafrost, infiltration, groundwater recharge, and runoff processes as climate, hydrology, and vegetation change (DeBano, 1991; DeFries and Eshleman, 2004; Osterkamp et al., 2009). Deforestation increases soil bulk density and decreases soil porosity, both of which alter infiltration, percolation, aeration, and erodibility (Reiners et al., 1994). Increased active layer thickness over permafrost, as a result of the warming climate, allows more subsurface water storage, higher nutrient transport, and a deeper root zone, which is favorable for shrub expansion
(Sturm et al., 2005). Because they are interrelated but have an uncertain timing, it is important to consider - both separately and in combination - the climate, vegetation, and soil changes that may occur in future.

Simulations of future hydrological conditions in mountains are challenging due to the large biases between climate model outputs and locally observed hydroclimatic conditions as well as the seasonal nature of snow accumulation and depletion (Fowler et al., 2007; Bennett et al., 2012). In the climate perturbation method, also known as the delta change factor method, (e.g., Rasouli et al., 2014, 2015), observations are perturbed using the difference (delta) between modeled present and future climates. This method avoids the computational cost of dynamical downscaling and maintains consistency in relationships of the atmospheric fields, which may be distorted in statistical methods if the interaction of the variables is not considered (Hijmans et al., 2005; Gutmann et al., 2016). Unlike the direct use of regional climate model (RCM) outputs, the perturbation approach produces spatial and seasonal precipitation patterns based on observations, with the changes due to differences between present and future simulated climate (Hay et al., 2000; Kay et al., 2009; Sunyer et al., 2012). This represents weather with reasonable accuracy and also represents observed extremes such as dry periods and storms. Of particular importance for mountain hydrology is the realistic representation of the dynamics of precipitation, its phase, and its increase with elevation. Limitations of applying monthly climatological change factors to perturb the climate are that any future changes in large-scale weather patterns and their impact on extremes, and sequences of wet or dry spans are not adequately represented. This is similar to the assumption of stationarity in the relationships between large-scale circulations and locally observed data that are made in statistical downscaling. Changes in synoptic dynamics of the atmosphere cannot be captured by the climate perturbation method, nor can RCMs capture local-scale processes in mountainous regions (Rasouli, 2017).

There have been many studies on the impact of climate change on hydrology and some on mountain hydrology (e.g. Link et al., 2004; Flerchinger et al., 2012; Fang et al., 2013; Pomeroy et al., 2003, 2012, 2015; Rasouli et al., 2014; Williams et al., 2015). The present study builds on the recent understanding of the impact of climate perturbations on three headwater basins in the North American Cordillera where future reduced snowfall amounts are offset by reduced losses due to snow sublimation and increased rainfall amounts are offset by increased evapotranspiration, together leading to insignificant changes in annual runoff (Rasouli et al., 2019a). However, there are fewer studies that focus on the impacts of land surface changes on mountain hydrology. In most impact studies, changes in vegetation, soil, and land surface are not well represented, and there is limited knowledge about how the combination of climate, vegetation, and soil 
changes impacts hydrological processes and basin-level discharge (Brown et al., 2005).

Interactions between climate, vegetation, and soils are complex (Rodriguez-Iturbe, 2000) and the time lag between vegetation response to climate changes and soil response to climate and vegetation changes is unclear (Innes, 1991). In a warmer climate, with a longer snow-free season, and increased precipitation in northern latitudes, vegetation is expected to increase where adequate soil moisture and nutrients permit. Therefore, assuming there will be no change in vegetation in future climates introduces uncertainty and possible errors in hydrological impact studies of climate change. Modeling climate change effects on hydrology with and without vegetation and soil changes can help to understand the separate and combined effects of climate, vegetation, and soil changes in mountainous headwater basins. Rasouli et al. (2019a) show that future climates are warmer and wetter, especially in the northern latitudes, and that temperature and precipitation changes have complex effects in snow-dominated watersheds. Warmer and wetter future conditions are expected to drive vegetation, soil, and hydrological changes, but such changes have not been thoroughly studied. The objective of this study is to investigate the hydrological changes due to climate perturbations, building on Rasouli et al. (2019a), and plausible concomitant soil and vegetation changes, adapted from Alberta Natural Regions Committee (2006), Schneider et al. (2009), and Myers-Smith and Hik (2018) for three instrumented headwater basins ranging from middle to high latitudes in the North American Cordillera.

\section{Methods}

\subsection{Study sites and data sources}

Three mountain basins ranging from middle to high latitudes in the North American Cordillera are examined: a subarctic basin (Wolf Creek Research Basin $\sim 61^{\circ} \mathrm{N}$, Yukon Territory, Canada), a headwater catchment in the Canadian Rockies (Marmot Creek Research Basin, $\sim 51^{\circ} \mathrm{N}$, Alberta, Canada), and a small catchment with a cool montane climate (Reynolds Mountain East catchment, hereafter called Reynolds Mountain, $\sim 43^{\circ}, \mathrm{N}$, Idaho, USA) (Fig. 2). All three basins are located in transition climate zones based on the Köppen climate classification (Köppen 1936). Wolf Creek has the shortest distance to the Pacific Ocean (Fig. 1), the lowest average elevation, the coldest climate, and the lowest annual precipitation amongst the three basins. Marmot Creek has the highest elevation, the largest elevation range, and the highest annual precipitation and wind speed. Reynolds Mountain has the smallest drainage area, the highest average elevation, and the lowest wind speed (Table 1).

Jack pine, spruce, and aspen forests are the dominant vegetation types at low elevations in Wolf Creek (Francis et al.,
1998), and $65 \%$ of the basin area above the forest biome is covered with birch and willow shrub tundra with heights ranging between $30 \mathrm{~cm}$ and $2 \mathrm{~m}$. Alpine tundra with short moss, grass, and bare rock covers high elevations in Wolf Creek. Engelmann spruce and subalpine fir cover high elevations and lodgepole pine stands cover low elevations in Marmot Creek (Kirby and Ogilvie, 1969). Areas adjacent to the treeline in Marmot Creek are covered with shrubs and alpine larch. The alpine zone is composed of grass, moss, and large areas of bare rock. The spatial variability of vegetation is large within the Reynolds Mountain area (Seyfried et al., 2009; Winstral and Marks, 2014), and grass, mountain sagebrush, riparian willow, aspen, and coniferous trees are the dominant vegetation types in this basin. Almost $43 \%$ of Wolf Creek is covered by continuous and discontinuous permafrost (Lewkowicz and Ednie, 2004). Soils do not freeze in Reynolds Mountain and freeze seasonally in Marmot Creek.

Precipitation was measured using a tipping-bucket rain gauge, an unshielded "BC-style standpipe", and Niphershielded storage gauges in Wolf Creek, using an Altershielded Geonor storage gauge in Marmot Creek, and using shielded and unshielded storage gauges in Reynolds Mountain. Snowfall observations were adjusted using wind undercatch correction equations (Goodison et al., 1998; Smith, 2009) based on wind-shield and wind speeds measured at gauge height. Air temperature, humidity, wind speed, shortwave radiation, and streamflow were measured and stored at hourly time steps for each basin. Suitable driving meteorological time series from these observations were available for 1993-2011 in Wolf Creek, 2005-2014 in Marmot Creek, and 1983-2008 in Reynolds Mountain. Long-term datasets and descriptions of the variables for each basin were published by Reba et al. (2011), Fang et al. (2019), and Rasouli et al. (2019b).

\subsection{Modeling strategy}

As described in Rasouli et al. (2019a), a distinctive distributed hydrological model for each basin was developed on the Cold Regions Hydrological Modeling platform (CRHM; Pomeroy et al., 2007). The models represent the major hydrological mechanisms in cold regions and those found in these basins, including snow transport and redistribution by wind, snow interception, snow sublimation, sub-canopy radiation, energy balance snowmelt, mass and energy balance evapotranspiration, infiltration, and runoff over frozen and unfrozen soils (e.g., Pomeroy et al., 1999; MacDonald et al., 2009). Parameters for modeling each hydrological process were obtained from field measurements in the basins or similar basins following the deduction-induction-abduction approach outlined by Pomeroy et al. (2013). The models were discretized into hydrological response units (HRUs) that are spatially segregated based on hydrological function and parameter as defined by vegetation type, elevation, slope and aspect, soil depth, soil layers, hydrography, and the variabil- 


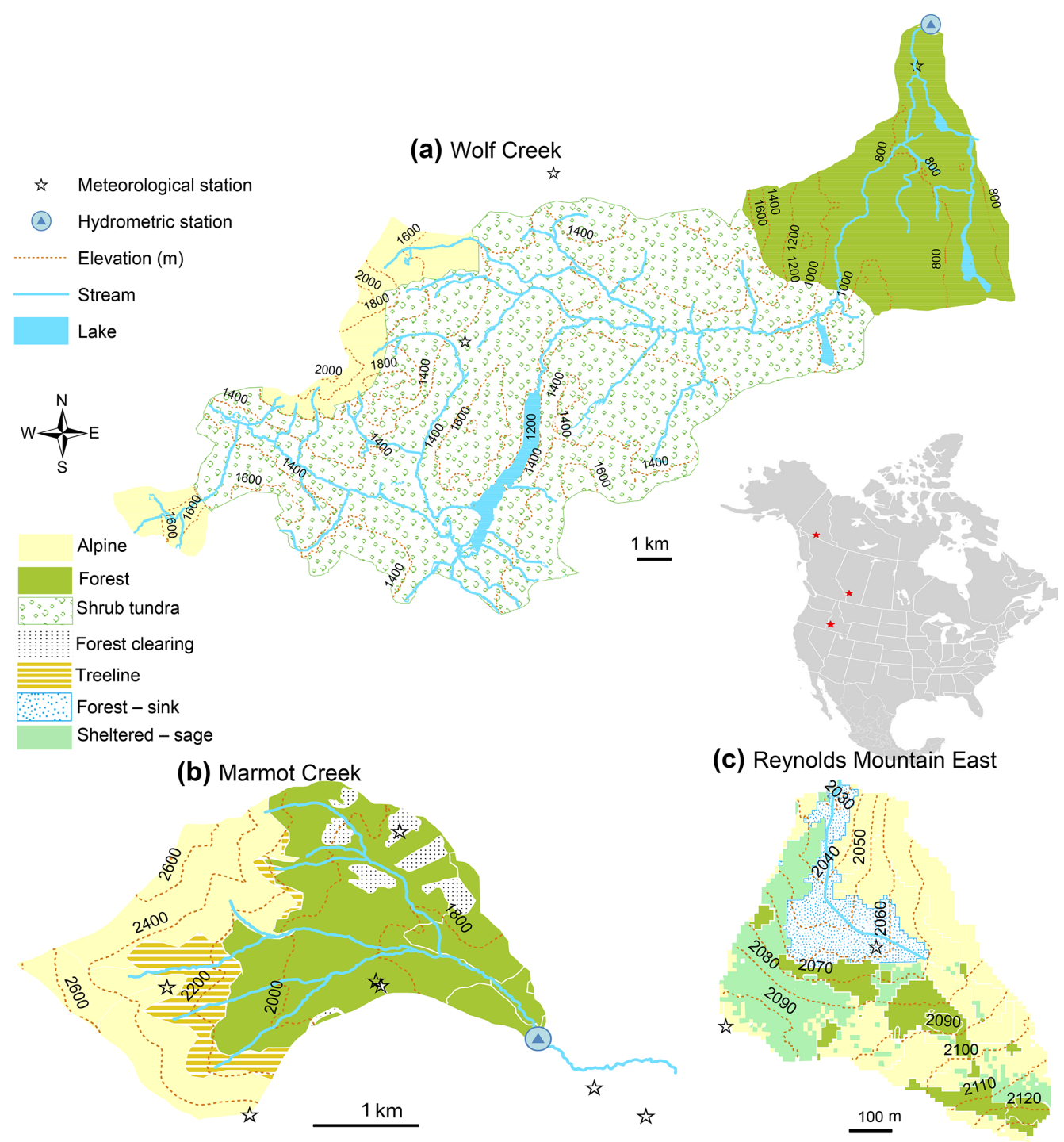

Figure 1. Vegetation, hydrography, topography, and meteorological stations of the three headwater study basins: (a) Wolf Creek Research Basin, Yukon Territory, Canada; (b) Marmot Creek Research Basin, Alberta, Canada; and (c) Reynolds Mountain within the Reynolds Creek Experimental Watershed, Idaho, USA.

ity of basin attributes. The CRHM models were run at hourly time steps (Table 1). Details on model parametrization and performance are available in Rasouli et al. $(2014,2015)$ and Rasouli (2017).

Eight change cases were used to differentiate the individual and combined effects of changes in climate $(\Delta C)$, vegetation $(\Delta V)$, and soils $(\Delta S)$ from the present conditions (base case). The vegetation and soil changes applied are conceptualized in Fig. 2 and summarized in Table 2. The effects of vegetation and soil changes on snow regimes and hydrological variables were evaluated under conditions in which: (1) climate does not change, but vegetation and/or soil changes occur $(\Delta V S),(2)$ climatic conditions change but no changes in future vegetation and/or soil occur $(\Delta C)$, and (3) changes in future climate will be accompanied by vege- tation and soil changes $(\Delta C V, \Delta C S$, and $\triangle C V S)$. Porosity and soil depth are expected to change as a result of vegetation and climate change. The specific vegetation and soil changes applied in each watershed were different based upon the current understanding of likely future terrestrial ecosystems in each of these three basins. In Wolf Creek, the vegetation changes were an upslope movement of the treeline and expansion of shrub tundra into former sparse tundra in response to a warmer and wetter climate (Fig. 2a). In Marmot Creek, the changes were an upward movement of the treeline, afforestation of areas harvested in the 1970s and 1980s, and deforestation of the lower elevations due to fire and disease in a warmer climate (Fig. 2b). In Reynolds Mountain, the changes were deforestation of all trees (aspen, fir, and willow) and expansion of mountain sage due to a warmer 
Table 1. Comparison of physiography and climatology amongst the three basins. UC denotes the "Upper Clearing" meteorological station in the Marmot Creek Research Basin.

\begin{tabular}{|c|c|c|c|}
\hline Characteristics & Wolf Creek & Marmot Creek & Reynolds Mountain \\
\hline Latitude & $60^{\circ} 36^{\prime} \mathrm{N}$ & $50^{\circ} 57^{\prime} \mathrm{N}$ & $43^{\circ} 11^{\prime} \mathrm{N}$ \\
\hline Longitude & $134^{\circ} 57^{\prime} \mathrm{W}$ & $115^{\circ} 09^{\prime} \mathrm{W}$ & $116^{\circ} 47^{\prime} \mathrm{W}$ \\
\hline Drainage area $\left(\mathrm{km}^{2}\right)$ & 179 & 9.4 & 0.38 \\
\hline Elevation range $(\mathrm{m})$ & $660-2080$ & $1600-2825$ & $2028-2137$ \\
\hline Record period & 1993-2011 & 2005-2014 & 1983-2008 \\
\hline \multicolumn{4}{|l|}{ Dominant vegetation cover } \\
\hline High elevation & Tundra moss & Rock and grass & Grass and sage \\
\hline Middle elevation & Shrub tundra & Spruce and fir & Fir \\
\hline Low elevation & Spruce & Lodgepole pine & Aspen and willow \\
\hline Climate zone & $\begin{array}{l}\text { Cordillera and } \\
\text { subarctic }\end{array}$ & $\begin{array}{l}\text { Cordillera, prairie, } \\
\text { and boreal }\end{array}$ & $\begin{array}{l}\text { Cordillera, continental } \\
\text { and Mediterranean }\end{array}$ \\
\hline Elevation bands & 3 & 3 & 1 \\
\hline \multicolumn{4}{|l|}{ Temperature $\left({ }^{\circ} \mathrm{C}\right)$} \\
\hline High elevation & -3.4 & -1.8 & 5.0 \\
\hline Middle elevation & -2.0 & $1.0(\mathrm{UC})$ & - \\
\hline Low elevation & -1.5 & 2.9 & - \\
\hline \multicolumn{4}{|l|}{ Number of freezing days } \\
\hline High elevation & 224 & 217 & 120 \\
\hline Middle elevation & 203 & 166 (UC) & \\
\hline Low elevation & 179 & 128 & \\
\hline Precipitation (mm) & 380 & 1011 & 858 \\
\hline Wind speed $\left(\mathrm{m} \mathrm{s}^{-1}\right)$ & 3.7 & 5.8 & 1.9 \\
\hline Relative humidity (\%) & 74 & 69 & 61 \\
\hline Number of subbasins \& HRUs & $5 \& 29$ & $4 \& 36$ & $1 \& 12$ \\
\hline HRU area range $\left(\mathrm{km}^{2}\right)$ & $0.92-25.4$ & $0.01-1.37$ & $0.01-0.07$ \\
\hline
\end{tabular}

Table 2. Description of the eight cases of change in climate, vegetation, and soils.

\begin{tabular}{llll}
\hline Climate & Vegetation and soil case & $\begin{array}{l}\text { Notation used } \\
\text { in text }\end{array}$ & Actual change \\
\hline Present & Present vegetation and present soil & Base & No change \\
Present & Future vegetation and present soil & $\Delta V$ & Only vegetation \\
Present & Present vegetation and future soil & $\Delta S$ & Only soil \\
Present & Future vegetation and future soil & $\Delta V S$ & Both vegetation and soil \\
Future & Present vegetation and present soil & $\Delta C$ & Only climate \\
Future & Future vegetation and present soil & $\Delta C V$ & Both vegetation and climate \\
Future & Present vegetation and future soil & $\Delta C S$ & Both soil and climate \\
Future & Future vegetation and future soil & $\Delta C V S$ & Climate, vegetation, and soil \\
\hline
\end{tabular}

climate with persistent water deficits. Other combinations of these vegetation changes in the three basins were explored to examine hydrological uncertainty due to various terrestrial ecosystem trajectories; they produced similar results and are not presented here. Changes in the organic layer of soils following vegetation changes can alter the soil characteristics, including soil macropores and, hence, alter snowmelt and rainfall infiltration, thawing and freezing processes, recharge into groundwater, and runoff mechanisms. The soil porosity in different soil layers and soil depth were two soil model parameters that were altered to bring the changed soil char- acteristics in line with those currently associated with vegetation and land cover types (Fig. 2).

Hydrological model parameters that represented the current vegetation cover and soil characteristics in forest, shrub tundra, grass, sage, and alpine tundra were determined using field measurements in each basin. To represent soil change and vegetation conversion from one type to another in the model, the area being converted was added to or subtracted from an existing HRU with that vegetation and soil type, or parameters (vegetation, soil, or both) were modified in the converted HRUs. HRUs were altered to represent three dif- 

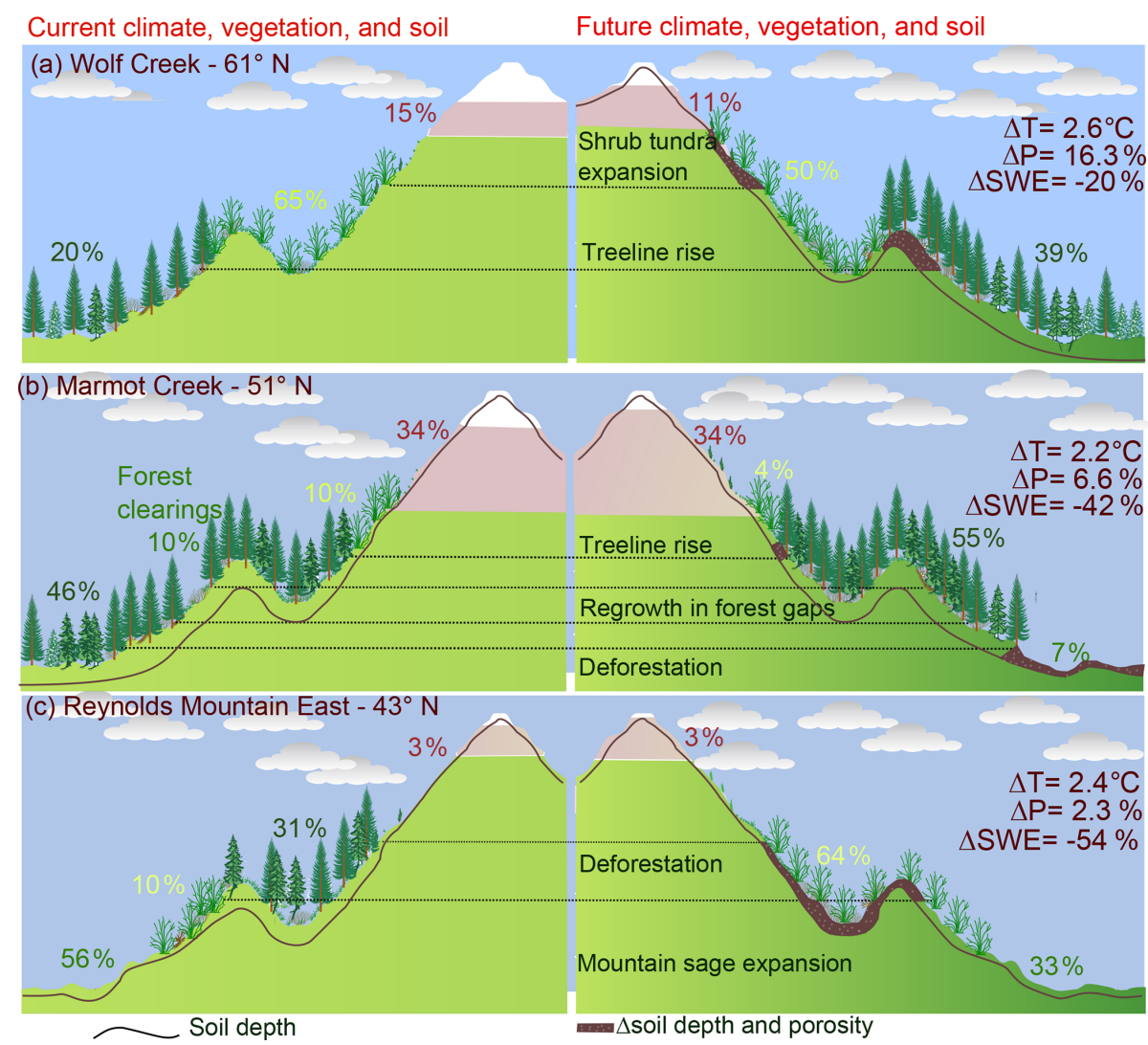

Figure 2. Schematic illustration of the vegetation cover under the base case and future climate, vegetation, and soil $(\Delta C V S)$ in the Wolf Creek Research Basin, the Marmot Creek Research Basin, and Reynolds Mountain. Dark shading indicates areas where changes to the soil are expected in future. The numbers show the areal percentage of the alpine, forest, shrub tundra, grassland, and forest clearing biomes. $\Delta T$, $\Delta P$, and $\Delta \mathrm{SWE}$ are from Rasouli et al. (2019a).

ferent changes (i) vegetation change only, (ii) soil change only, and (iii) both vegetation and soil change.

\subsection{Perturbed observations}

Monthly perturbed climates were constructed from a downscaling method applying delta changes in monthly climatology to base case hourly meteorological observations from various elevations in the research basins; see Rasouli et al. (2019a) for details. The monthly perturbation was determined from the results of 11 regional climate models from the North American Regional Climate Change Assessment Program (NARCCAP), which are driven by outputs from multiple global climate models (GCMs) for the SRES A2 emission scenario (Mearns et al., 2007). Using observed data modified by the monthly delta gives an estimate of the potential climate change impacts on these driving forces consistent with large-scale atmospheric circulations. The deltas used were the difference between the simulated current monthly 30-year climatology (1971-2000) and the future (2041-2070) monthly 30-year climatology (20412070) for 11 RCMs (Rasouli et al., 2019a).

\subsection{Significance testing}

Significant changes and differences in water balance components, snow characteristics, and their timing (initiation date, peak SWE date, snow-free date, and duration of snow cover season) between simulations under the present period (base case) and simulations under different cases of changes in climate $(\Delta C)$, vegetation $(\Delta V)$, and soil $(\Delta S)$ were assessed using a nonparametric Mann-Whitney $U$ test (Wilcoxon, 1945; Mann and Whitney, 1947). The differences between simulated distributions in the modeled present period for $n$ years $\left(x_{1: 11 \times n}^{c}, 11 \times n\right.$ values) and the simulated distributions in the modeled future periods, obtained for $11 \mathrm{RCMs}$ $\left(x_{1: 11 \times n}^{f}, 11 \times n\right.$ years), were determined (18 for Wolf Creek, 8 for Marmot Creek, and 25 for Reynolds Mountain). Assessment of the changes in the hourly SWE distribution due to vegetation changes was carried out using a nonparametric two-sample Kolmogorov-Smirnov test (Massey, 1951). This test evaluates the difference between the cumulative density functions of the hourly SWE in the present period and a climate or vegetation alternative. The confidence interval in the plots is based upon the standard deviation of the results for 
the 11 RCMs and the years of observations in each watershed.

\subsection{The Tukey honestly significant difference test}

An analysis of variance (ANOVA) was used to determine if there was a case that was different from the others. This test, however, does not provide information on the pattern of differences between the means of the eight cases (Table 2). The Tukey honestly significant difference (HSD) test (Tukey, 1991) is a widely used test to analyze the pattern of difference between means using pairwise comparisons. In the pairwise comparisons, the significant difference between a pair of means is determined using a statistical distribution that gives the exact sampling distribution of the largest difference between a set of means originating from the same population (Abdi and Williams, 2010). In this test, groups that are statistically different based upon paired comparison are labeled "a", "b", and so on, and are ordered by mean from lowest to highest. Using an analysis of variance on the annual differences between the modeled future and the modeled base case and the Tukey HSD test for each basin, differences in snow and runoff under the four groups of the eight cases were determined (Table 2).

\section{Results}

\subsection{Synergic effects of climate, vegetation, and soil changes on snow and runoff regimes}

Changes in simulated peak SWE and annual runoff volume due to vegetation, soil, and their interaction in the present climate $(\Delta V, \Delta S$, and $\Delta V S)$ were compared with the modeled present (base case; no changes in climate, vegetation, and soil) to determine the effect of individual or combined changes. Similarly, changes in simulated peak SWE and runoff due to changes in vegetation, soil, and their interaction in the future climate were compared with future-climate change as well as the present climate. In total, four cases under the present climate and four cases under the future climate were studied and statistical differences, based on the Tukey HSD test, were distinguished from the modeled present; all cases were then classified into multiple groups for each variable (Figs. 3, 4, 5).

In Wolf Creek (Fig. 3), the peak SWE declined significantly with $\Delta C$ (group "a") in the alpine biome (Fig. 3a), and increased insignificantly with $\Delta V$ and $\Delta V S$ in the present climate. Peak SWE decreased significantly with $\Delta C, \Delta C V$, $\triangle C S$, and $\triangle C V S$ (groups "a" and "b") in the shrub tundra biome (Fig. 3b), and did not change significantly with any combination of vegetation change and climate change in the forest biome (all eight cases are in group "a") (Fig. 3c). In the alpine biome within Wolf Creek, the effect of increasing alpine vegetation on increasing peak SWE (Fig. 3a) is not statistically significant by itself, but it was sufficient to offset the significant decrease in SWE from climate change. In contrast to the forest biome SWE in Wolf Creek, which is not affected by any changes (Fig. 3c), and to the alpine biome, where combined changes counteracted each other, the decrease in peak SWE in the shrub tundra biome due to climate change is intensified with concomitant vegetation change (Fig. 3b). Soil changes do not affect peak SWE in Wolf Creek. The annual runoff volume in Wolf Creek decreases significantly with $\Delta V, \Delta S$, and $\Delta V S$ change cases in the present climate and increases significantly for the future climate $\Delta C$, and $\triangle C S$ cases (Fig. 3d). The decrease in annual runoff with soil and vegetation changes $(\Delta V, \Delta S$, and $\Delta V S)$ in the present climate (groups "a" and "b") is offset by the increases in runoff with climate change (group "d"), such that the combined effects of climate, vegetation, and soil change ( $\triangle C V$ and $\Delta C V S$ ) on runoff in Wolf Creek are not different from the base case of current conditions.

In Marmot Creek (Fig. 4), the high-elevation alpine biome peak SWE showed no significant response to vegetation and/or climate changes (all eight cases are in group "a", Fig. 4a). In the forest biome, peak SWE declines with climate change ( $\Delta C$; group "a" vs. base case group "b", Fig. 4b). In the forest clearing and treeline biomes (Fig. 4d, e), there are significant decreases in peak SWE under $\Delta V$ and $\Delta V S$; in the forest clearing, these significant decreases are also seen with climate changes and all case combinations (groups "a" and b", Fig. 4c and d). Soil changes alone $(\Delta S)$ do not affect peak SWE in Marmot Creek. The annual runoff volume in Marmot Creek decreases with $\Delta V$ and $\Delta V S$ and increases with $\Delta C S$ (Fig. 4e). This counteracting behavior is evident in the response of annual runoff to $\triangle C$ and $\Delta C V S$, which is not significantly different from the base case (all are in group "b"). In contrast, the combined effect of climate and soil change ( $\triangle C S-$ "c" in Fig. 4e) is magnified from that of climate alone. Therefore, soil-climate interactions $(\triangle C S)$ are more important in changing annual runoff in Marmot Creek than the individual effects of soil and climate and are counteracted by concomitantly changing vegetation.

In Reynolds Mountain (Fig. 5), the alpine biome peak SWE decreases significantly under climate change $(\Delta C$; group "a", Fig. 5a). Significant decreases in peak SWE occur with both vegetation and climate change (groups "a" and "b") in the respective forest biome (Fig. 5b), the blowing wind sheltered zone (Fig. 5c), and the blowing snow sink zone (Fig. 5d). The peak SWE in all of the biomes in Reynolds Mountain shows significant decreases under climate, vegetation, and under a combination of the two (Fig. 5), except for the alpine biome, which shows a significant decrease only due to climate change (Fig. 5a). Similar to the other two basins, soil changes do not affect peak SWE in Reynolds Mountain. Climate change $(\Delta C)$ and soil change $(\triangle C S)$ do not affect the annual runoff volume, whereas vegetation change and combined vegetation and soil change $(\Delta V$ and $\Delta V S$, respectively) significantly decrease annual runoff (Fig. 5e). Although the individual effect of soil change on 

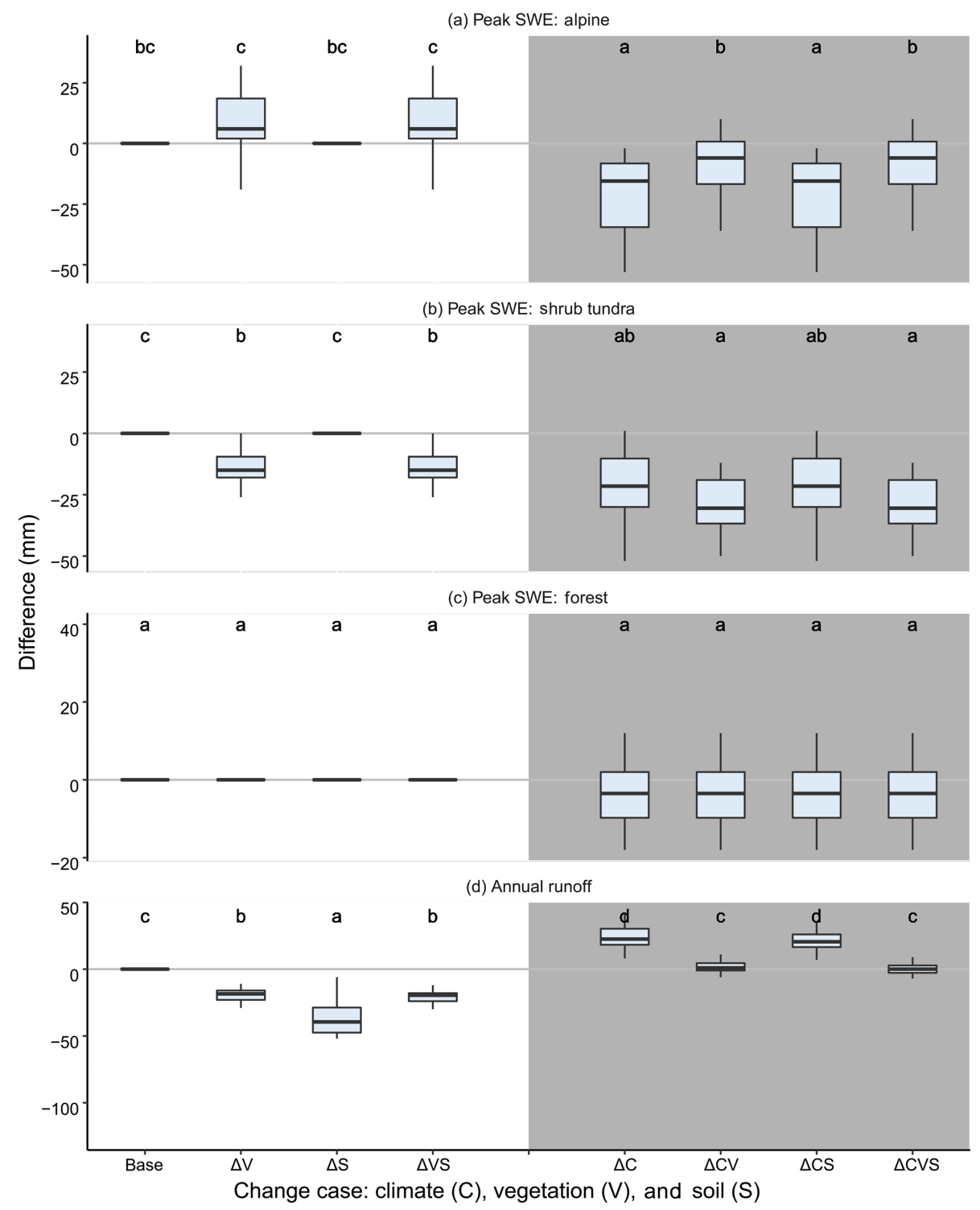

Figure 3. Differences in peak snow water equivalent (SWE) and annual runoff volume under seven combinations of changes in climate, vegetation, and soil in the Wolf Creek Research Basin relative to present climate, present vegetation, and present soil with no change (base). Lower case letters from the Tukey HSD test indicate groups that are significantly different from each other. The unshaded cases on the lefthand side of the plot demonstrate changes under modeled present climate, and the shaded cases on the right-hand side of the plot demonstrate vegetation and soil changes under modeled future-climate cases.

runoff is not statistically significant, its combined effect can enhance the effect of the vegetation change in diminishing annual runoff from this basin (Fig. 5e).

\subsection{Snow characteristics}

Basin-scale snow regime characteristics including peak SWE, length of the snow season, snow initiation date, mean annual peak SWE, and timing of snow-free date were simulated for current and future climate, vegetation, and soils in the three basins. Under the current climate, soil changes did not affect snow regime characteristics, and vegetation changes only decreased peak SWE in Marmot Creek (Table 3). Despite the decrease in the peak SWE at the basin scale in Marmot Creek and for certain biomes in all basins, the timing of the basin-scale snow season was found to be insensitive to vegetation and soil changes under present climate in all basins (Table 3). Soil modules do not affect snow calculations in the CRHM models, and so soil changes do not affect snow regimes (Table 3, compare columns 2 and 3 as well as 4 and 5). The basin-scale peak SWE is affected by both climate and vegetation changes, and the changes are 

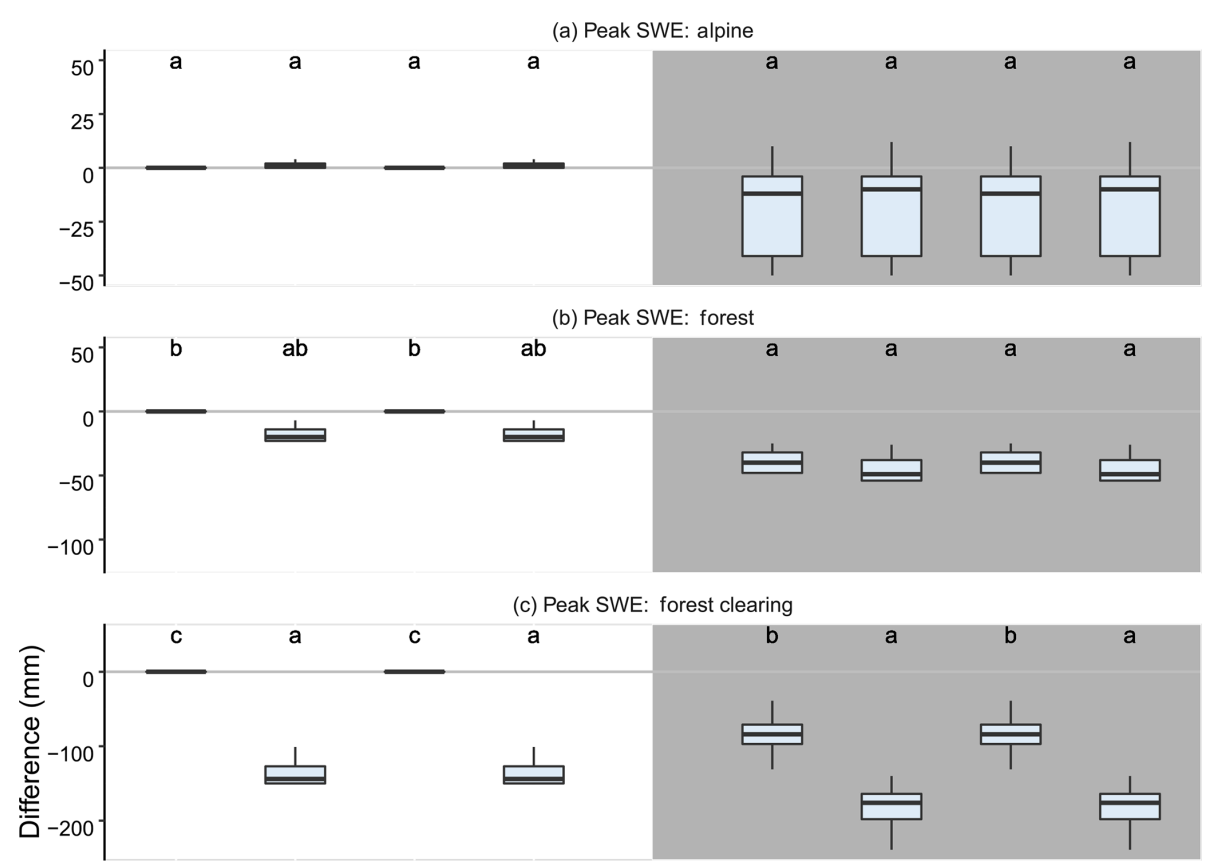

(d) Peak SWE: treeline
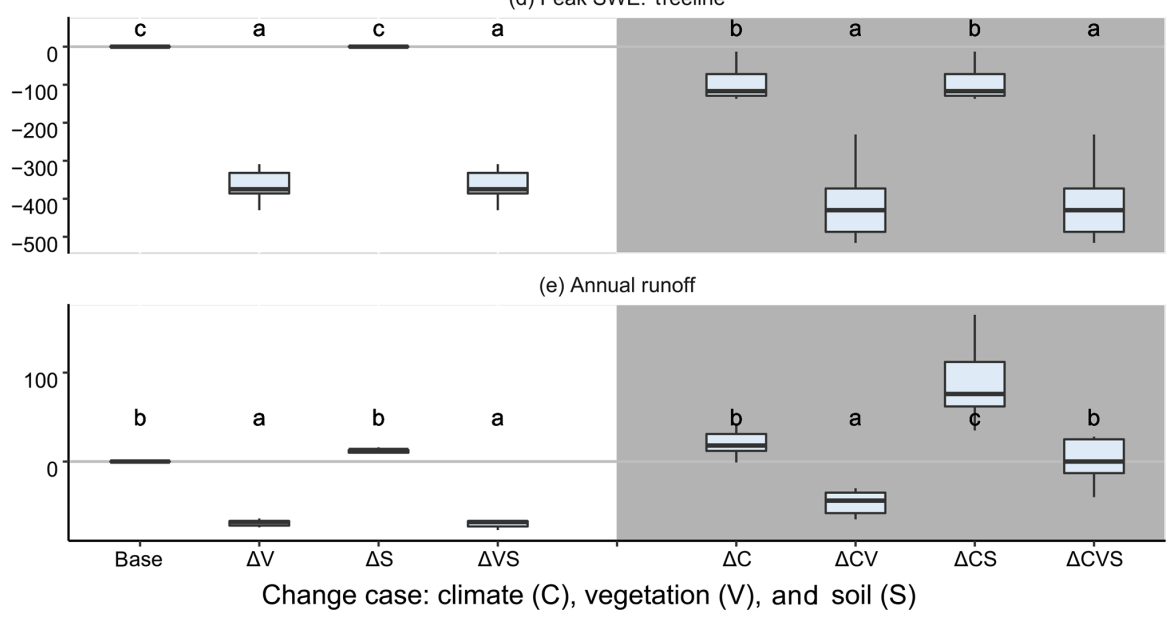

Figure 4. Differences in peak snow water equivalent (SWE) and annual runoff volume under seven combinations of changes in climate, vegetation, and soil in the Marmot Creek Research Basin relative to present climate, present vegetation, and present soil with no change (base). Lower case letters from the Tukey HSD test indicate groups that are significantly different from each other. The unshaded cases on the left-hand side of the plot demonstrate changes under modeled present climate, and the shaded cases on the right-hand side of the plot demonstrate vegetation and soil changes under modeled future climate.

statistically significant based on the Mann-Whitney $U$ test ( $p$ values $\leq 0.05$ ).

The difference between times series and their spread of the present and future peak SWE modeled using driving meteorology from 11 regional climate models $(11 \times n$ values $)$ for $n=18$ years for Wolf Creek, 9 years for Marmot Creek, and 25 years for Reynolds Mountain are shown in Fig. 6 and Table 4. Peak SWE decreases from $133 \mathrm{~mm}$ under the current climate to $118 \mathrm{~mm}$ (11\% decrease) under climate change and to $107 \mathrm{~mm}(20 \%)$ when vegetation change is considered in combination with climate change in Wolf Creek. In Marmot
Creek, peak SWE declines from the current climate value of 183 to $141 \mathrm{~mm}$ ( $23 \%$ decrease) under climate change and to $106 \mathrm{~mm}$ (42\% decrease) under combined climate and vegetation change. An increase in precipitation under climate change in the north and a large vegetation change in Marmot Creek as well as its effect on accumulated snow lead to similar future peak snowpacks in Marmot Creek and Wolf Creek. The peak SWE in Reynolds Mountain decreases from $368 \mathrm{~mm}$ in the current climate to $196 \mathrm{~mm}$ (47\% decrease) under climate change and to $168 \mathrm{~mm}(54 \%$ decrease) under combined climate and vegetation change. Considering only 

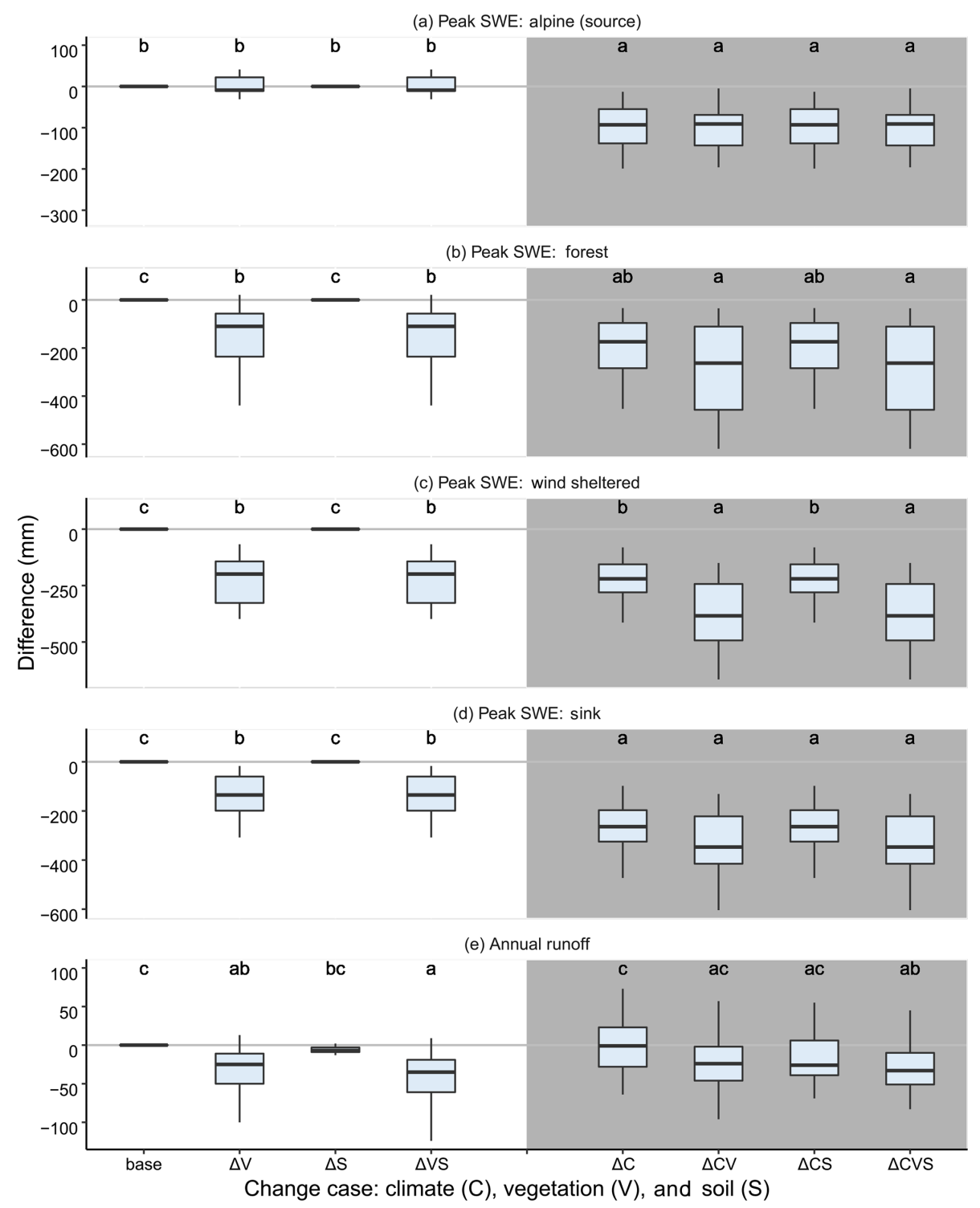

Figure 5. Differences in peak snow water equivalent (SWE) and annual runoff volume under seven combinations of changes in climate, vegetation, and soil in the Reynolds Mountain area relative to present climate, present vegetation, and present soil with no change (base case). Lower case letters from the Tukey HSD test indicate groups that are significantly different from each other. The unshaded cases on the left-hand side of the plot demonstrate changes under modeled present climate, and the shaded cases on the right-hand side of the plot demonstrate vegetation and soil changes under modeled future climate.

vegetation changes under the current climate, the peak SWE decreases more in Marmot Creek (26\%) than in Wolf Creek and Reynolds Mountain (11\%). Therefore, under the combined climate and vegetation change studied in this research, the maximum accumulated SWE is the most stable in Wolf Creek and most sensitive in Reynolds Mountain.

The significant responses to vegetation change $(\Delta V$ in Figs. 3-5) shows that vegetation change in all three basins has an important effect on snow and runoff regimes, except for the snow regimes in the alpine and forest biomes in Marmot Creek. Figure 6 shows the snowpack regimes in vari- ous current biomes and at various elevations for the three basins under current (base), changed climate $(\Delta C)$, changed vegetation $(\Delta V)$, and both changed climate and vegetation $(\triangle C V)$ cases with shading to reflect interannual variability. The simulated snowpack regimes for $\Delta C, \Delta V$, and $\Delta C V$ are significantly ( $p$ value $\leq 0.05$ ) different from the base case in each biome shown in Fig. 6 (Kolmogorov-Smirnov test); however, there are important variations in how they differ. With $\Delta V$, SWE in Wolf Creek develops a greater peak and ablates more slowly, and the snow cover season becomes longer (Fig. 6a). This is mostly due to shrub expansion into 
Table 3. Simulated basin-scale snow characteristics under current climate and future vegetation and soil for the three basins. Values in italic font denote significant changes with $p$ values of less than 0.1 . Changes relative to current climate/vegetation/soil and are given in parentheses.

\begin{tabular}{|c|c|c|c|c|c|c|c|c|c|c|c|c|}
\hline \multirow{2}{*}{$\begin{array}{l}\text { Variable } \\
\text { (1) Wolf Creek }\end{array}$} & \multicolumn{3}{|c|}{$\begin{array}{l}\text { Current climate, } \\
\text { current vegetation, } \\
\text { and current soil }\end{array}$} & \multicolumn{3}{|c|}{$\begin{array}{r}\text { Current climate } \\
\text { and } \Delta \text { soil }\end{array}$} & \multicolumn{3}{|c|}{$\begin{array}{l}\text { Current climate } \\
\text { and } \Delta \text { vegetation }\end{array}$} & \multirow{2}{*}{\multicolumn{3}{|c|}{$\begin{array}{c}\text { Current climate and } \\
\Delta \text { soil and vegetation }\end{array}$}} \\
\hline & & & & & & & & & & & & \\
\hline Peak SWE (mm) & & & 133 & & & 133 & $118-1$ & $33(-11$ & to 0$)$ & 118 & $133(-$ & 11 to 0$)$ \\
\hline Initiation (date) & & & 5 & & & 5 & & & $5(0)$ & & & $5(0)$ \\
\hline Peak SWE (date) & & & 186 & & & 186 & $182-18$ & $5(-4 t$ & $-1)$ & $182-$ & $85(-$ & to -1 ) \\
\hline Snow-free (date) & & & 250 & & & 250 & 250 & $-252(0$ & to 2$)$ & & $50-252$ & (0 to 2$)$ \\
\hline Season length (day) & & & 224 & & & 224 & 224 & $-226(0$ & to 2) & & $24-226$ & (0 to 2 ) \\
\hline \multicolumn{13}{|l|}{ (2) Marmot Creek } \\
\hline Peak SWE (mm) & & & 183 & & & 183 & $136-16$ & $8(-26$ & $o-8)$ & 136 & $68(-2$ & 6 to -8$)$ \\
\hline Initiation (date) & & & 9 & & & 9 & & & $9(0)$ & & & $9(0)$ \\
\hline Peak SWE (date) & & & 210 & & & 210 & & & $1(1)$ & & & $211(1)$ \\
\hline Snow-free (date) & & & 294 & & & 294 & 294 & $-296(0$ & to 2 ) & & $4-296$ & (0 to 2$)$ \\
\hline Season length (day) & & & 283 & & & 283 & 283 & $-284(0$ & to 1$)$ & & $33-284$ & (0 to 1$)$ \\
\hline \multicolumn{13}{|l|}{ (3) Reynolds Mountain } \\
\hline Peak SWE (mm) & & & 368 & & & 368 & $326-3$ & $75(-11$ & to 2) & $326-$ & $375(-$ & 11 to 2$)$ \\
\hline Initiation (date) & & & 35 & & & 35 & & & $5(0)$ & & & $35(0)$ \\
\hline Peak SWE (date) & & & 161 & & & 161 & 162 & $-168(1$ & to 7 ) & & 62-168 & (1 to 7$)$ \\
\hline Snow-free (date) & & & 246 & & & 246 & & & $7(1)$ & & & 247 (1) \\
\hline Season length (day) & & & 211 & & & 211 & 212 & $-213(1$ & to 2) & & $2-213$ & (1 to 2 ) \\
\hline First day of & Oct & Nov & Dec & Jan & Feb & Mar & Apr & May & Jun & Jul & Aug & Sep \\
\hline Day of water year & 1 & 32 & 62 & 93 & 124 & 152 & 183 & 213 & 244 & 274 & 305 & 336 \\
\hline
\end{tabular}

higher elevations under $\Delta V$, which reduces blowing snow transport and subsequent sublimation of blowing snow and also slows snowmelt rates (Pomeroy et al., 2006). Changes in the rate of snowmelt can be assessed by comparison of the slope of the curve during the ablation period in Fig. 6. There is no change in the slope between the base case and $\triangle C V$ in the alpine and forested biomes of Wolf Creek (Fig. 6a-c) or in the alpine biomes of Marmot Creek (Fig. 6d); however, these slopes decrease under $\Delta C V$ at the middle elevations in Wolf Creek, the lower elevations in Marmot Creek, and at all elevations in Reynolds Mountain (Fig. 6e-k), indicating a slower melt rate. Under $\triangle C V$, the effect of climate change on the alpine snowpack is moderated by the impact of the shrub tundra expansion into high-elevation alpine tundra. However, at middle elevations, shrubs are expected to be replaced by forest; therefore, under $\Delta C V$, the peak snowpack decreases from 156 to $127 \mathrm{~mm}$ (19\% decrease, Fig. 6b). Vegetation change is expected to be negligible at low elevations in Wolf Creek; therefore, the snowpack is only disturbed by climate change impacts in these simulations (Fig. 6c).

In Marmot Creek, the anticipated advance of trees into alpine tundra causes a small increase in the simulated peak SWE and slower ablation rates at high elevations under the $\Delta V$ scenario (Fig. 6d). In contrast to greater snowpacks with upward movement of the treeline $(\Delta V)$, climate change alone $(\Delta C)$ slightly decreases peak SWE in the alpine biome. The treeline acts as an important sink for blowing snow transport and accumulates deep snowdrifts; thus, the effect of treeline movement out of the upper middle elevations $(\Delta V)$ on reducing snowpacks is even greater than that of climate change ( $\Delta C$; Fig. 6e). This is due to the suppression of snow redistribution to the former treeline with afforestation and subsequent sublimation of intercepted snow in newly forested needleleaf canopies, which is enhanced by climate change $(\triangle C V)$. At low elevations, snow accumulation decreases from 87 to $39 \mathrm{~mm}(48 \mathrm{~mm})$ under combined climate change and conversion of forest to shrub and grass (Fig. 6f). Forest clearings currently store deep snowpacks; however, with regrowth of harvested forest, the peak snow will decrease as intercepted snow sublimation increases (Fig. 6g). Climate change has less impact than forest regrowth in these harvested clearings. In Marmot Creek, the impact of vegetation change on peak snowpack timing offsets the impact of climate change. The date of the peak SWE is delayed with only $\Delta V$ and advanced with only $\Delta C$ (Table 3 ).

In Reynolds Mountain, all blowing snow regimes except for the depressions and valley bottom (Fig. 6i) will receive a more uniform SWE under $\Delta V$ as the forest canopy disap- 

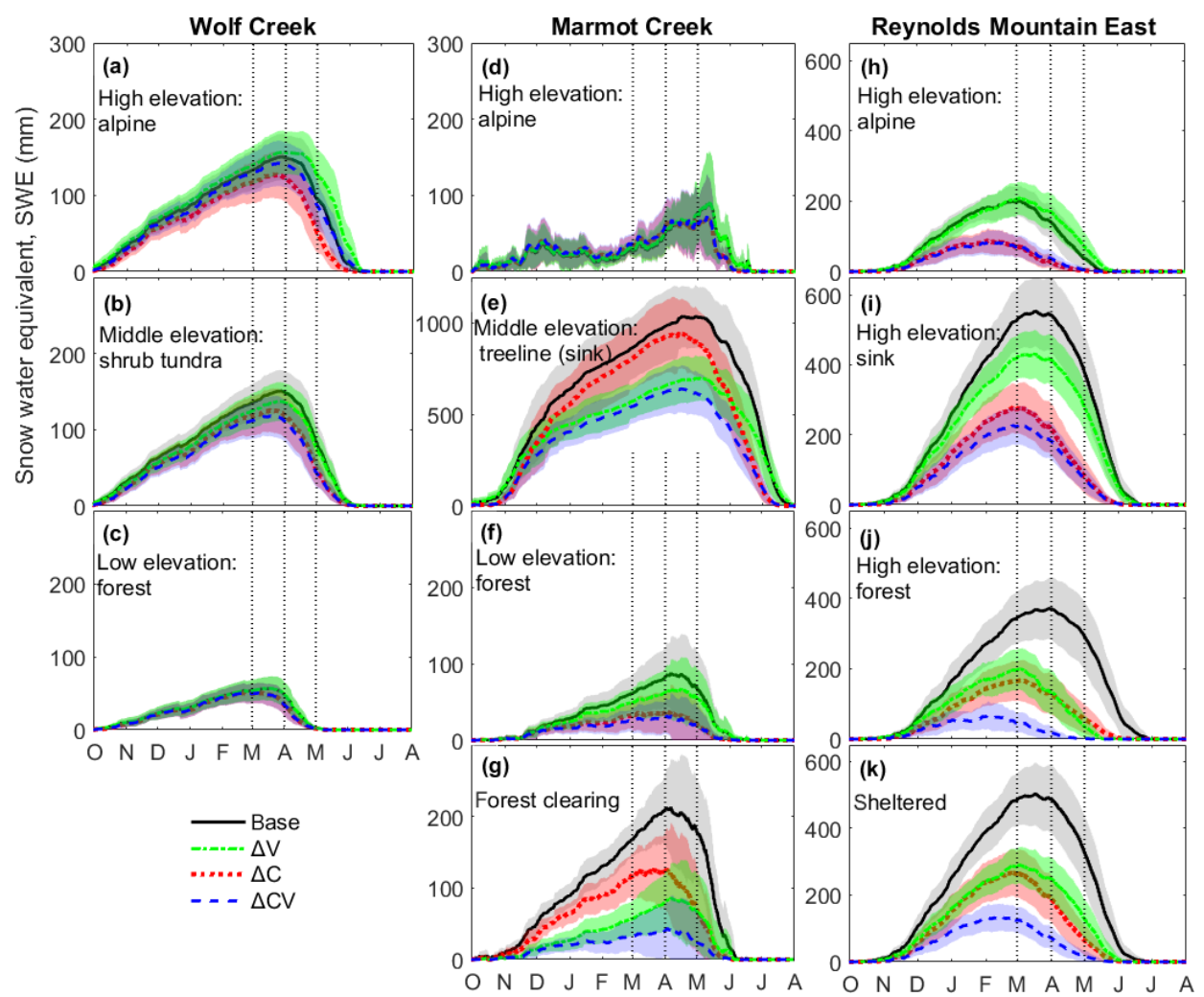

Figure 6. Simulated snowpack accumulation and ablation under current climate and vegetation (base scenario) and changes due to climate and vegetation changes at different elevation levels and in current biomes in the Wolf Creek Research Basin, the Marmot Creek Research Basin, and Reynolds Mountain. Reynolds Mountain only has one elevation band but multiple blowing snow regimes. The $95 \%$ confidence intervals shown by the shaded areas indicate the interannual variability. The three vertical lines denote the first days of March, April, and May, respectively.

pears. Despite the small impact of vegetation change in the alpine biome which is covered with grass and short mountain sages, the impact of $\Delta C$ on the snowpack in this biome is large (Fig. 6h). The forest biome in the Reynolds Mountain area is most sensitive to $\Delta C V$, based on a large decrease in the peak snowpack (Fig. 6j). The interannual variability of SWE, which is expressed as $95 \%$ confidence intervals in Fig. 6, becomes smaller in all of the biomes within the three basins under climate perturbation because the snowpack becomes shallower under $\Delta C V$ and variability of the shallow snowpack becomes smaller. This can occur despite an increased variability of precipitation under future climate conditions. The interannual variability of SWE does not change in the alpine biome under $\Delta V$.

Snow regimes are the most resilient to $\Delta C V$ at high elevations in Wolf Creek and Marmot Creek and low elevations in Wolf Creek, with less than a $10 \%$ decrease in peak SWE. In contrast, snow regimes in the forest clearings in Marmot Creek and in the forest and sheltered sites in Reynolds Mountain are very sensitive to $\Delta C V$, with $80 \%$ and $68 \%$ decreases, respectively, due to the role of canopy changes enhancing climate change impacts with respect to reducing SWE. Under $\Delta V$, peak SWE drops from 87 to $46 \mathrm{~mm}$ (a
$47 \%$ decrease) at low elevations in Marmot Creek with the conversion of forest into grassland. Impacts of $\Delta C$ on snow regimes can be enhanced or dampened by the impact of $\Delta V$. Shrub tundra expansion into the higher elevations in Wolf Creek can substantially dampen the impact of climate change on the snowpack because it suppresses blowing snow transport and sublimation. However, forest expansion above the current treelines or into forest clearings enhances $\Delta C$ impacts on the snowpack by introducing the sublimation of intercepted snow. Therefore, the impact of shrubification or afforestation on the snowpack can be as important as the impact of climate change.

\subsection{Precipitation phase}

With warmer air temperatures and increased precipitation, snowfall events become less frequent as the precipitation phase shifts from snowfall to rainfall (Fig. 7). For the three basins (Fig. 7), and their biomes (Fig. 8), the portion of total precipitation that is rainfall increases in all of the basins under climate changes (vegetation change does not affect the precipitation phase). Furthermore, annual rainfall rises to $238 \mathrm{~mm}$ from the $413 \mathrm{~mm}$ of annual precipitation (a rain- 
Table 4. Simulated snow characteristics under current and monthly perturbed climate and future vegetation and soil in the three basins. Bold and italic values denote significant changes with $p$ values of less than 0.05 and 0.1 , respectively. Changes, relative to current climate/vegetation/soil, are given in parentheses. Dates are given in water year days.

\begin{tabular}{|c|c|c|c|c|c|c|c|c|c|c|c|c|c|}
\hline \multirow[t]{2}{*}{ Variable } & \multirow{2}{*}{$\begin{array}{c}\text { Base } \\
\text { Mean }\end{array}$} & \multicolumn{3}{|c|}{$\begin{array}{c}\Delta \text { Climate, } \\
\text { current vegetation, and soil }\end{array}$} & \multicolumn{3}{|c|}{$\begin{array}{c}\Delta \text { Climate and } \\
\Delta \text { soil }\end{array}$} & \multicolumn{3}{|c|}{$\begin{array}{c}\Delta \text { Climate and } \\
\Delta \text { vegetation }\end{array}$} & \multicolumn{3}{|c|}{$\begin{array}{c}\Delta \text { Climate, } \\
\Delta \text { soil, and } \Delta \text { vegetation }\end{array}$} \\
\hline & & $5 \%$ & Mean & $95 \%$ & $5 \%$ & Mean & $95 \%$ & $5 \%$ & Mean & $95 \%$ & $5 \%$ & Mean & $95 \%$ \\
\hline \multicolumn{14}{|l|}{ (1) Wolf Creek } \\
\hline \multirow{5}{*}{$\begin{array}{l}\text { Peak SWE (mm) } \\
\text { Initiation (date) } \\
\text { Peak SWE (date) } \\
\text { Snow-free (date) } \\
\text { Season length (day) }\end{array}$} & 133 & 73 & $118(-11)$ & 153 & 73 & $118(-11)$ & 153 & 64 & $107(-20)$ & 142 & 64 & $107(-20)$ & 142 \\
\hline & 5 & 0 & $7(2)$ & 47 & 0 & $7(2)$ & 47 & 0 & $7(2)$ & 45 & 0 & $7(2)$ & 45 \\
\hline & 186 & 143 & $164(-22)$ & 178 & 143 & $164(-22)$ & 178 & 148 & $164(-22)$ & 170 & 148 & $164(-22)$ & 170 \\
\hline & 250 & 213 & $235(-15)$ & 248 & 213 & $235(-15)$ & 248 & 216 & $236(-14)$ & 249 & 216 & $236(-14)$ & 249 \\
\hline & 224 & 160 & $208(-16)$ & 242 & 160 & $208(-16)$ & 242 & 164 & $215(-9)$ & 251 & 164 & $215(-9)$ & 251 \\
\hline \multicolumn{14}{|l|}{ (2) Marmot Creek } \\
\hline \multirow{5}{*}{$\begin{array}{l}\text { Peak SWE (mm) } \\
\text { Initiation (date) } \\
\text { Peak SWE (date) } \\
\text { Snow-free (date) } \\
\text { Season length (day) }\end{array}$} & 183 & 102 & $141(-23)$ & 170 & 102 & $141(-23)$ & 170 & 74 & $106(-42)$ & 130 & 74 & $106(-42)$ & 130 \\
\hline & 9 & 4 & $24(15)$ & 62 & 4 & $24(15)$ & 62 & 4 & $24(15)$ & 63 & 4 & $24(15)$ & 63 \\
\hline & 210 & 175 & $200(-10)$ & 216 & 175 & $200(-10)$ & 216 & 177 & $205(-5)$ & 223 & 177 & $205(-5)$ & 223 \\
\hline & 294 & 257 & $281(-13)$ & 295 & 257 & $281(-13)$ & 295 & 257 & $283(-11)$ & 299 & 257 & $283(-11)$ & 299 \\
\hline & 283 & 204 & $248(-35)$ & 277 & 204 & $248(-35)$ & 277 & 200 & $246(-37)$ & 276 & 200 & $246(-37)$ & 276 \\
\hline \multicolumn{14}{|c|}{ (3) Reynolds Mountain } \\
\hline \multirow{5}{*}{$\begin{array}{l}\text { Peak SWE (mm) } \\
\text { Initiation (date) } \\
\text { Peak SWE (date) } \\
\text { Snow-free (date) } \\
\text { Season length (day) }\end{array}$} & 368 & 105 & $196(-47)$ & 277 & 105 & $196(-47)$ & 277 & 91 & $168(-54)$ & 237 & 91 & $168(-54)$ & 237 \\
\hline & 35 & 20 & $50(15)$ & 85 & 20 & $50(15)$ & 85 & 19 & $49(14)$ & 83 & 19 & 49 (14) & 83 \\
\hline & 161 & 102 & $129(-33)$ & 148 & 102 & $129(-33)$ & 148 & 96 & $127(-34)$ & 149 & 96 & $127(-34)$ & 149 \\
\hline & 246 & 184 & $213(-33)$ & 232 & 184 & $213(-33)$ & 232 & 195 & $220(-26)$ & 236 & 195 & $220(-26)$ & 236 \\
\hline & 211 & 113 & $161(-50)$ & 197 & 113 & $161(-50)$ & 197 & 129 & $171(-40)$ & 200 & 129 & $171(-40)$ & 200 \\
\hline & \multicolumn{2}{|c|}{ First day of } & $\begin{array}{ll}\text { Oct } & \text { Nov }\end{array}$ & Dec & Jan & $\mathrm{Feb}$ & Apr & May & Jun & Aug & Sep & & \\
\hline & Day of wa & er year & 32 & 62 & 93 & 124 & 183 & 213 & 244 & 305 & 336 & & \\
\hline
\end{tabular}

fall ratio of 0.58) in Wolf Creek, $550 \mathrm{~mm}$ from $1027 \mathrm{~mm}$ (a rainfall ratio of 0.54) in Marmot Creek, and $473 \mathrm{~mm}$ from $866 \mathrm{~mm}$ (a rainfall ratio 0.55) in Reynolds Mountain. For all of the basins, the currently snowfall-dominated elevations, ranging between 650 and $2500 \mathrm{~m}$, are expected to become more rainfall-dominated under climate change.

\subsection{Snow transport and redistribution}

The modeled snow redistribution due to blowing snow transport in and out of the basin and transport between biomes within a basin is an important component of the water budget that has been assessed in this study (Figs. 7, 8). Under $\triangle C V$, the annual average blowing snow transport remains unchanged in Wolf Creek, whereas it declines $14 \mathrm{~mm}$ (from 131 to $117 \mathrm{~mm}$ ) in Marmot Creek and $11 \mathrm{~mm}$ (from 24 to $13 \mathrm{~mm}$ ) in Reynolds Mountain (Fig. 7). Snow transport at high elevations in Marmot Creek declines $11 \mathrm{~mm}$ under $\Delta C$ and increases $23 \mathrm{~mm}$ due to shorter fetches as the treeline moves upslope with concomitant vegetation change $(\Delta C V)$. Therefore, the impact of climate change in reducing snow redistribution from the alpine biome in Marmot Creek is almost completely offset by vegetation change. At lower elevations where the treeline current exists, snow transport decreases $56 \mathrm{~mm}$ under $\Delta C$, likely due to higher threshold wind speeds for transport and a shorter snow season. Snow transport in the valley bottom and the blowing snow sink regime in Reynolds Mountain, presently covered with a willow forest, also decreases substantially from 79 to $37 \mathrm{~mm}$ (a $42 \mathrm{~mm}$ decrease, $p$ value $\leq 0.05$ ) under climate change and deforestation $(\triangle C V)$.

\subsection{Sublimation}

The annual sublimation from all sources, including snow intercepted on the canopy, snow surface, and blowing snow was examined under climate and vegetation changes and is shown in Figs. 7 and 8. Sublimation from snow intercepted on the canopy in Wolf Creek dominates the annual sublimation, which is expected to increase in this basin as the treeline moves upward to higher elevations. In Marmot Creek, annual sublimation increases $15 \mathrm{~mm}$ (Fig. 7, 119 to $134 \mathrm{~mm}$ ) under $\Delta V$ but decreases $7 \mathrm{~mm}$ under $\Delta V C$ (Fig. 7 , 119 to $112 \mathrm{~mm}$ ). The impact of vegetation on sublimation rates in Reynolds Mountain is negligible, whereas climate change decreases sublimation from 31 to $10 \mathrm{~mm}$. Vegetation change enhances sublimation to varying degrees in the different biomes of the three basins. Sublimation is suppressed by increasing shrub tundra in higher elevations. However, $\Delta V$ causes sublimation to increase moderately in the Mar- 

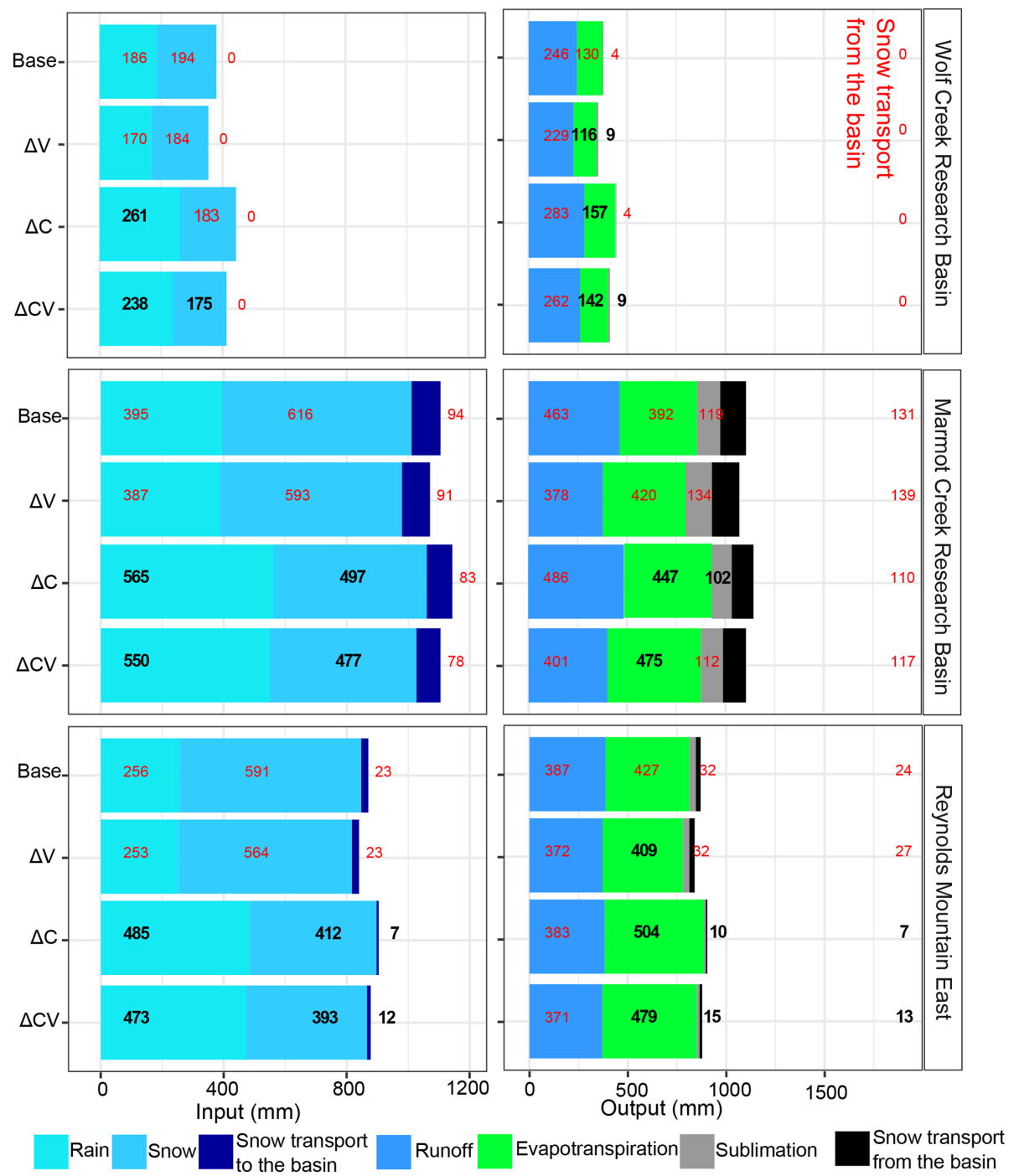

Figure 7. Mean modeled water fluxes, in the (three) liquid, vapor, and snow states, under current climate and current vegetation (base), future climate and current vegetation $(\Delta C)$, current climate and future vegetation $(\Delta V)$, and future climate and future vegetation $(\Delta V C)$ in the Wolf Creek Research Basin, the Marmot Creek Research Basin, and Reynolds Mountain. Statistically significant differences in the climatological mean of the simulated variables with $p$ values of less than 0.05 are represented using bold and black values.

mot Creek and Wolf Creek basins due to enhanced sublimation of intercepted snow. Vegetation change does not affect sublimation in Reynolds Mountain.

\subsection{Evapotranspiration (ET)}

$\Delta V$ also alters the annual evapotranspiration (ET). The simulations show that, under $\Delta V$, annual ET increases $28 \mathrm{~mm}$ (from 392 to $420 \mathrm{~mm}$, Fig. 7) as a result of afforestation of the clearings and upward movement of the treeline in Marmot Creek. In contrast, ET decreases $14 \mathrm{~mm}$ in Wolf Creek (from 130 to $116 \mathrm{~mm}$, Fig. 7) and $18 \mathrm{~mm}$ in Reynolds Mountain (from 427 to $409 \mathrm{~mm}$, Fig. 7). Increases in ET due to $\Delta C$ can be partially offset by concomitant vegetation change in Wolf Creek and Reynolds Mountain. ET increases the most in Marmot Creek, from 392 to $475 \mathrm{~mm}(83 \mathrm{~mm}, p$ value $<0.05$ ), and the least in Wolf Creek, from 130 to $142 \mathrm{~mm}$ $(12 \mathrm{~mm})$, under both vegetation change and climate change. Under $\Delta V C$, ET changes significantly in different elevation bands (Fig. 8). The increase in ET due to $\Delta C V$ varies with elevation within each basin and reaches $23 \mathrm{~mm}$ at high elevations and $9 \mathrm{~mm}$ at low elevations in Wolf Creek, $61 \mathrm{~mm}$ at low elevations and $249 \mathrm{~mm}$ at the treeline elevations in Marmot Creek, and $32 \mathrm{~mm}$ in the forest and $98 \mathrm{~mm}$ at the sheltered site in Reynolds Mountain (Fig. 8). This also shows the high variability of the annual ET amongst these three basins. 


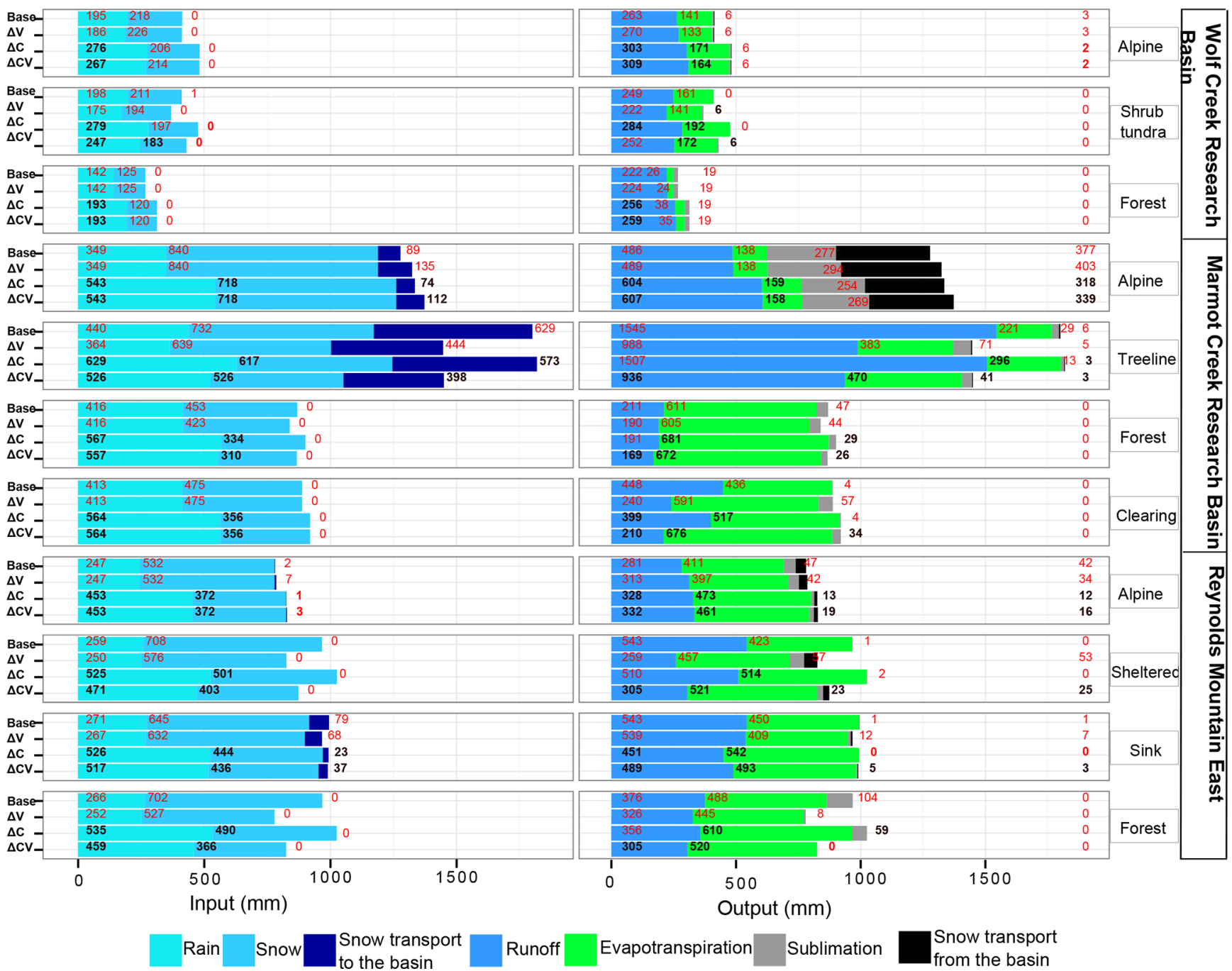

Figure 8. Mean modeled water fluxes, in the (three) liquid, vapor, and snow states, on an elevation/vegetation basis under current climate and current vegetation (base), current climate and future vegetation $(\Delta V)$, future climate and current vegetation $(\Delta C)$, and future climate and future vegetation $(\Delta V C)$ in the Wolf Creek Research Basin, the Marmot Creek Research Basin, and Reynolds Mountain. Statistically significant differences in the climatological mean of the simulated variables with $p$ values of less than 0.05 are represented using bold and black values.

\subsection{Runoff characteristics}

$\Delta V$ decreases the annual runoff volume in Wolf Creek, which counteracts the increasing effect of climate change on the annual runoff volume (Table 5, Fig. 3d). Changes in soil and vegetation decrease the annual runoff volume in Marmot Creek (Table 5, Fig. 4e). With $\Delta V C$, the annual runoff volume decreases in Marmot Creek, while under combined climate-soil changes it increases (Table 5, Fig. 4e). This shows that a combination of all factors, vegetation, and soil changes have the largest, intermediate, and lowest effects, respectively, and climate change has no effect on the annual runoff volume in Marmot Creek. In Reynolds Mountain, change in annual runoff is evidenced only under current climate and future vegetation (Table 5, Fig. 5e).
The average annual hydrographs for the present and future climate simulations under vegetation and soil changes are shown in Fig. 9. With $\Delta V$, high flows are lower in all three basins, particularly in Wolf Creek (Fig. 9a). $\Delta C$ causes the occurrence of high flows to be earlier in Wolf Creek (Fig. 9b), leads to no change in Marmot Creek (Fig. 9d), and causes a shift to much earlier high flows in Reynolds Mountain (Fig. 9f). Climate change $(\Delta C)$ and soil change $(\Delta S)$ do not cause significant changes in the annual runoff volumes in Marmot Creek and Reynolds Mountain, whereas in Wolf Creek climate change $(\Delta C)$ increases and soil change $(\Delta S)$ decreases the annual runoff volume (246 to $210 \mathrm{~mm}$, Table 4, Fig. 3d). The combined effect of climate-vegetation change $(\triangle C V)$ in these simulations advanced the snow-free date by $14 \mathrm{~d}$ in Wolf Creek, $11 \mathrm{~d}$ in Marmot Creek, and 
Table 5. Simulated runoff characteristics including annual volume under current and monthly perturbed climates and future vegetation in the three basins. Bold and italic values denote significant changes with $p$ values of less than 0.05 and 0.1 , respectively, based on a Mann-Whitney $U$ test. Simulated distributions with $n=18$ years for Wolf Creek, 9 years for Marmot Creek, and 25 years for Reynolds Mountain over the present (base case) period for each hydrological variable are compared with the simulated future distributions obtained from 11 regional climate models $(11 \times n$ values). The percentage change, relative to the current climate/vegetation, is given in parentheses.

\begin{tabular}{llrrr}
\hline Change case & & Wolf Creek & Marmot Creek & Reynolds Mountain \\
\hline No change & Base & 246 & 402 & 371 \\
Future vegetation & $\Delta V$ & $228-262(-7$ to +7$)$ & $336-373(-16$ to -7$)$ & $340-379(-8$ to +2$)$ \\
Future soil & $\Delta S$ & $210(-15)$ & $335(-17)$ & $331(-11)$ \\
Future soil and vegetation & $\Delta V S$ & $\mathbf{1 7 3 ( - 3 0 )}$ & $411(2)$ & $365(-2)$ \\
Future climate & $\Delta C$ & $286(16)$ & $426(6)$ & $375(1)$ \\
Future climate and vegetation & $\Delta V C$ & $265(8)$ & $359(-11)$ & $351(-5)$ \\
Future climate and soil & $\Delta S C$ & $250(2)$ & $414(3)$ & $342(-8)$ \\
Future climate, soil, and vegetation & $\Delta C V S$ & $282(15)$ & $\mathbf{4 9 2}(\mathbf{2 2})$ & $368(-1)$ \\
Number of simulation years & & 18 & 9 & 25 \\
\hline
\end{tabular}

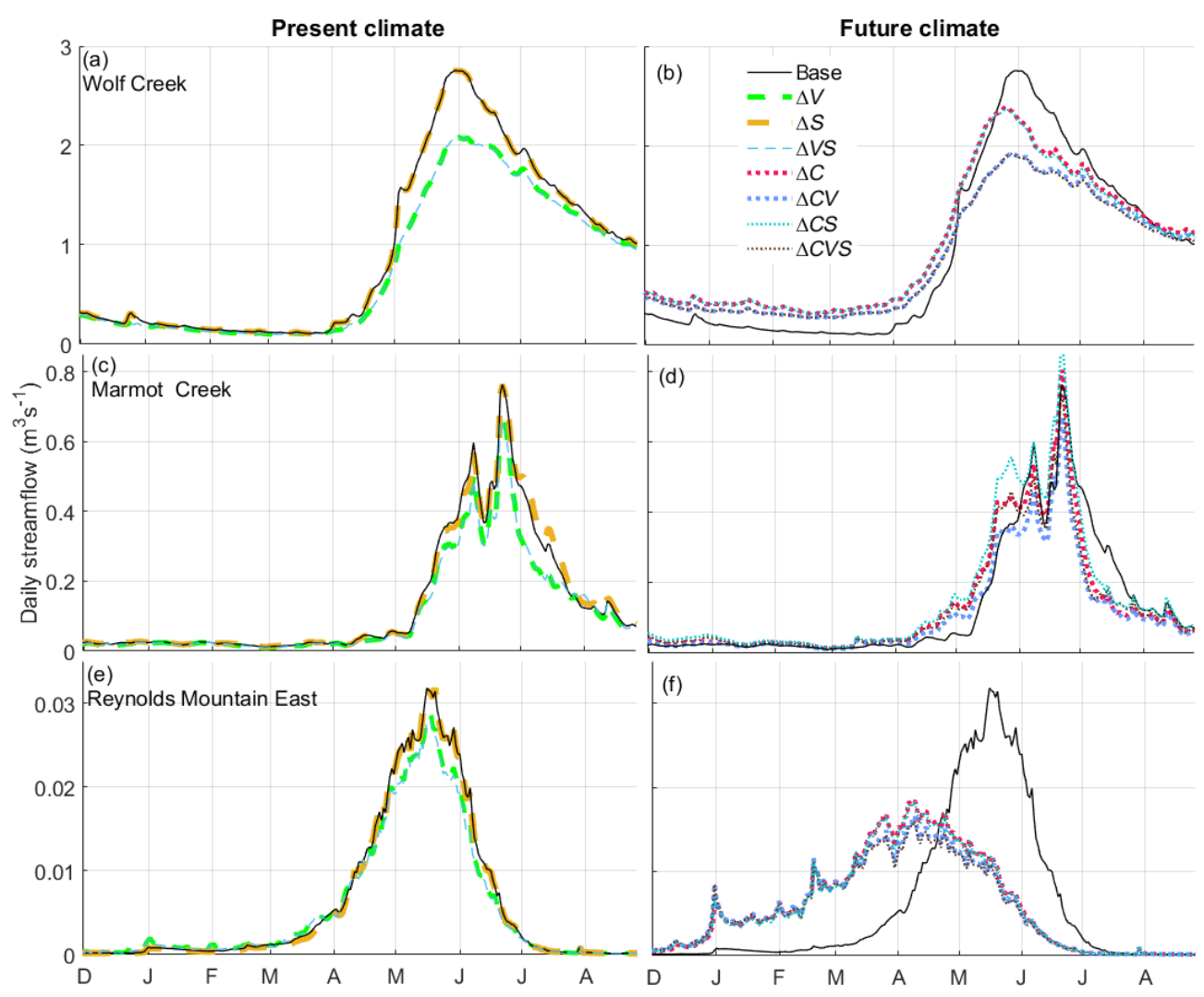

Figure 9. Annual average hydrographs under present climate, present vegetation, and present soil (base); present climate, future vegetation, and present soil $(\Delta V)$; present climate, present vegetation, and future soil $(\Delta S)$; present climate, future vegetation, and future soil $(\Delta V S)$; future climate, present vegetation, and present soil $(\Delta C)$; future climate, future vegetation, and present soil $(\Delta C V)$; future climate, present vegetation, and future soil $(\triangle C S)$; and future climate, future vegetation, and future soil $(\triangle C V S)$ in the three basins.

$46 \mathrm{~d}$ in Reynolds Mountain and decreased the length of the snow cover season by 9, 37, and $40 \mathrm{~d}$ in Wolf Creek, Marmot Creek, and Reynolds Mountain, respectively (Table 4). $\triangle C V$ delayed the snow accumulation initiation date by $15 \mathrm{~d}$ in Marmot Creek and $14 \mathrm{~d}$ in Reynolds Mountain. The beginning of the melt season under $\triangle C V$, measured from the timing of peak SWE, advanced $22 \mathrm{~d}$ (4 April to 13 March) in Wolf Creek, and 34 d (10 March to 4 February) in Reynolds Mountain (Table 4). The shift in the timing of the melt season was reflected in the runoff timing (Fig. 9b, f; Table 4). 


\section{Discussion}

The interaction of vegetation, soil, and climate changes can either result in large changes in snow and runoff regimes or they can offset the effect of one another. For instance, an insignificant increase in peak SWE in the alpine biome in Wolf Creek under $\Delta V$ can become important with concomitant climate change in that it can offset the climate change effect under $\Delta C V$ (Fig. 3a). $\Delta V$ decreases the annual runoff in Wolf Creek, whereas $\Delta C$ counteracts the effect of vegetation change and increases the annual runoff with $\Delta C V$ (Fig. 3d). The individual effects of soil change $(\Delta S)$ and climate change $(\Delta C)$ on annual runoff in Marmot Creek are statistically insignificant, but when they are combined $(\triangle C S)$, the effect of the combination is enhanced, leading to a statistically significant increase in the annual runoff volume (Fig. 4e). Therefore, the increase in the annual runoff volume by climate change $(\Delta C)$ is offset by the vegetation change effect $(\triangle C V)$ in Wolf Creek, and it is enhanced by the soil change effect $(\Delta S)$ in Marmot Creek, whereas the effect of climate change $(\Delta C)$ on annual runoff in Reynolds Mountain is not significant, and vegetation change $(\Delta V)$ is the main driver of the runoff changes in this basin. A decreasing effect of vegetation change on annual runoff in Marmot Creek is offset by a combined soil and climate change ( $\triangle C V S$ and base are in the same group in Fig. 4e). This suggests that not only climate change but also vegetation and soil changes affect hydrological processes in cold regions, and small changes can trigger significant hydrological changes if changes concur. Therefore, consideration of all vegetation, soil, and climate changes in impact studies is necessary (Pielke, 2005), especially in basins with nearfreezing winter air temperatures such as Reynolds Mountain, where vegetation-atmosphere interactions are complex and nonlinear and can dampen or amplify climate change (Bonan, 2008).

Similar to findings of Musselman et al. (2017) in the mountains of the western USA and southwestern Canada, future snowmelt rates with combined climate and vegetation change were found to be slower than the present-climate rates in Reynolds Mountain and lower elevations in Marmot Creek (Fig. 6f-k). In contrast, snowmelt rates under the combined effect of climate change and anticipated shrub expansion into alpine tundra in Wolf Creek (Fig. 6a) and upslope forest expansion in Marmot Creek (Fig. 6d) remained similar to the present-climate rates. Shrub expansion into higher elevations prolongs the snow season and increases peak SWEs, counteracting the climate change impact on snowmelt. Therefore, relative to the base case, no change in the future snowmelt was found under vegetation and climate changes in cold and high-elevation environments. Although these snowmelt rates did not decelerate under climate change as Musselman et al. (2017) found in warmer environments, neither did they accelerate as found by Krogh and Pomeroy (2019) in a colder Arctic basin located $1000 \mathrm{~km}$ north of Wolf Creek.
Under combined climate and vegetation changes in Wolf Creek, the precipitation and the rainfall ratio increase (Fig. 8), peak SWE declines (Table 4), ET and sublimation increase (Fig. 8), and the snow season period shortens (Table 4), which result in no change in annual total runoff (Fig. 3d). This implies that the climate change effect that increases annual runoff in Wolf Creek is offset by the vegetation change effect that decreases annual runoff, and the increased precipitation effect is offset by the increased sublimation and ET effects in this same region (Rasouli et al., 2019a). Unlike Wolf Creek, the annual runoff volume declines under combined climate and vegetation changes ( $\triangle C V$ case) in Marmot Creek (Fig. 4e), which is due to significant decreases in sublimation and snow transport and an increase in ET (Figs. 8, 9). The response of simulated annual total runoff to climate and vegetation changes varies. Annual runoff increases from Reynolds Mountain in the south to Wolf Creek in the north under only climate as well as climate-soil changes, consistent with the findings of Nijssen et al. (2001). Annual runoff increases with climate change in Wolf Creek (Fig. 3d) and Marmot Creek (Fig. 4e), and decreases with only vegetation or vegetation-soil changes in all three basins, consistent with Bosch and Hewlett (1982), and with only soil changes in Wolf Creek (Fig. 3e). Despite the snow regime in Reynolds Mountain, which is sensitive to both climate and vegetation changes, only vegetation change affects annual total runoff (Fig. 5e). Vegetation change moderates the impact of climate change on ET to some extent by decreasing ET in Wolf Creek and Reynolds Mountain (Figs. 7, 8). Under a combined climate and vegetation change, ET increases in the three basins across the North American Cordillera (Fig. 7). The response of the peak SWE to climate and vegetation changes leads to a complex response of the annual runoff when the soil and precipitation phase changes are also considered. Changes in runoff characteristics become statistically significant when combined climate-vegetation-soil changes $(\triangle C V S)$ occur in Reynolds Mountain (Fig. 5e), climate-soil changes $(\triangle C S)$ occur in Marmot Creek (Fig. 4e), and soil-vegetation changes $(\Delta V S)$ occur in Wolf Creek (Fig. 3e).

A deep snowpack is deposited at middle elevations in Marmot Creek due to the strong winds, which scour blowing snow from the higher elevations to the treeline (MacDonald et al., 2010). Under the simulations presented in this paper and ongoing vegetation growth, alpine vegetation and shrubs in the treeline will eventually convert to forest, which can change the snow regime from a present-day blowing snow sink to a future forest with intercepted snow on the canopy. A simulated snow regime change at middle elevations in Marmot Creek leads to a substantial decrease in the maximum accumulated snowpack (Fig. 4c). This is because of the shift in the forest role from slowing snowmelt by shading the snow and sheltering the snow from wind to accelerating midwinter snowmelt by removal of the forest canopy (Lundquist et al., 2013). The peak SWE at low elevations also declines un- 
der future deforestation and climate change in Marmot Creek (Figs. 4b, 7f). This is because sublimation from blowing snow within the deforested portion of the lower elevations becomes more important than sublimation from intercepted snow on the canopy before deforestation. A higher sublimation rate on the slopes with no vegetation cover has also been reported by Liston et al. (2002). Furthermore, forest regrowth delays snow ablation because of the lower net radiation under the canopy relative to clearings with no canopy (Gelfan et al., 2004; Ellis et al., 2010). The impact of afforestation on the snowpack in the forest clearings is stronger than that of climate change. Therefore, an enhanced snowpack decline is expected in forest clearings under climate and vegetation changes (Figs. 4c, 7g).

Sublimation losses do not only vary from one basin to another but vary among the different elevation bands within each basin. For instance, at high elevations in Wolf Creek, shrub tundra expansion enhances the sublimation by increasing the snowpack. In contrast, both snowpack and sublimation decrease under climate change. This shows that, in the alpine biome of Wolf Creek, the impact of vegetation change on sublimation can be as important as the impact of climate change and a combined climate and vegetation change leads to an unchanged sublimation rate. At middle elevations in Wolf Creek, which are currently covered by shrub tundra, a treeline shift into the shrub tundra biome increases sublimation, whereas the opposite is true under climate change when snowpack and sublimation both decrease. No changes are expected in the sublimation at low elevations in Wolf Creek. Similar to Wolf Creek, the impact of a combined climate and vegetation change on sublimation in Marmot Creek varies with elevation. It causes an $8 \mathrm{~mm}$ decrease at high elevations as a result of the upward movement of the treeline, a $12 \mathrm{~mm}$ increase in the treeline blowing snow sink regime as shrubs turn to forest, and a $21 \mathrm{~mm}$ decrease at low elevations as forest becomes uncovered and the snowpack becomes shallower with warming. Different mechanisms are responsible for these changes; annual sublimation decreases in the alpine biome with the upward movement of the treeline as sublimation from blowing snow drops with upslope forest expansion. At middle elevations, bushes are replaced by trees and sublimation from intercepted snow on their canopy slightly increases. The combination of topographic gradients and types of vegetation plays an important role in snow redistribution and blowing snow sublimation. The highest wind-driven redistribution of snow and the highest sublimation occurs on leeward slopes, where there is little or no vegetation cover (Liston et al., 2002). At low elevations in Marmot Creek, sublimation from intercepted snow on the canopy decreases as deforestation occurs. This also occurs in the deforested zone in Reynolds Mountain where sublimation significantly decreases from 104 to $8 \mathrm{~mm}$ as a result of decreased available snow combined with deforestation under climate change.

Shrub tundra expansion to higher elevations (Myers-Smith and Hik, 2018), a community height increase (Bjorkman et al., 2018), and an increase in tree growth rates (Innes, 1991) have shifted the windblown snow drifts into higher elevations (Figs. 4a, 6a), which has offset the climate warming effect on decreasing peak SWE in the alpine biome at Wolf Creek (Fig. 3a). A 20\%-60\% increase in tundra height is expected by the end of the century (Bjorkman et al., 2018), which may change snow redistribution and soil moisture availability in the higher latitudes. Despite a long snow cover period at higher elevations with shrub tundra expansion, which may slow the growth rate, snow insulates and warms the soil and increases the productivity chance, leading to more expansion of warmth-demanding vegetation types such as shrub tundra (Lamprecht et al., 2018). The balance of these feedbacks in the future may depend on the changes in air temperature, snow redistribution, and soil moisture, as well as their interactions (Lawrence and Swenson, 2011).

In different biomes in each basin, the timing of the basinscale snow cover season was found to be insensitive to vegetation and soil changes under present climate (Table 3). This result differs from other studies that have found snow cover to be sensitive to vegetation on the prairies (Pomeroy and Gray, 1994), in the Alps (Keller et al., 2005) and in shrub tundra (Pomeroy et al., 2006). Biomes that are insensitive in our study are located at cold, high elevations, where the snowpack is more resilient (Rasouli et al., 2019a).

The simulation results presented here consider one futureclimate scenario (SRES A2) and generalized vegetation and soil changes that can be expected. The simulations compare "snapshots" in time contrasting eight steady-state conditions based upon a monthly climate perturbation that, in turn, is based upon RCM projections which have preserved the past history of observed weather in these three basins. Future weather may not necessarily resemble what has been observed in the past. While steady-state conditions are useful for examining the complex interactions between the effects of changes in climate, vegetation, and soil, as presented here, transient models that could capture the sequence of asynchronous changes in climate, vegetation, and soil, and potential feedback are needed to fully understand the ongoing changes in mountain watersheds.

Shifts in the timing of snow accumulation and snowmelt seasons have important consequences and can change the timing, rate, and amount of runoff in snow-dominated mountain basins (Callaghan et al., 2011). The simulation results presented here demonstrate that the interactions of changes in climate, vegetation, and soils are complex. Studies that consider the future impacts of climate change should not exclude consideration of the role of future vegetation.

\section{Conclusions}

Snow and runoff in three headwater mountain basins along the North American Cordillera are vulnerable to changes in climate, vegetation, and soil. A physically based semi- 
distributed hydrological model driven with monthly perturbed climate based on observations and modeled changes in monthly climatology was used to explore the effects of these changes. Changes in monthly climatology were obtained from 11 regional climate models. Climate changes, vegetation changes, and soil changes each affect cold regions' hydrological mechanisms. The effects of vegetation changes can be as large as those of climate change alone and decrease peak SWE at middle elevations, as well as sublimation amounts. Shrub tundra expansion to higher elevations in Wolf Creek shifted the windblown snow drifts into higher elevations, which offset the climate warming effect on decreasing peak SWE in the alpine biome. At high elevations, the impact of climate change on peak SWE, snow transport in Reynolds Mountain, ET, and annual total runoff is partially offset by the impact of vegetation change.

Simulations suggest that under both climate change and soil changes, annual total runoff is expected to gradually increase from Reynolds Mountain in the south to Wolf Creek in the north of the cordillera. With both vegetation and soil changes, annual runoff will decrease. Simulations suggest that with all three changes (climate, vegetation, and soil) annual runoff will decrease in Reynolds Mountain, and remain unchanged in the Marmot and Wolf creeks. The annual runoff volume decrease under soil change is larger than the annual runoff volume increase under climate change in Wolf Creek. Furthermore, the soil change has a more important role than the vegetation change in decreasing runoff volume in Wolf Creek. To some extent, the interaction of soil-climate changes moderates the counteracting decreasing effect of soil change and the increasing effect of climate change on annual runoff volume. Interaction of soil-climate changes also has a more important role in increasing the annual runoff volume than the effect of climate change alone, soil change alone, or an interaction of all three soil-vegetation-climate changes in Marmot Creek. Further investigation in other mountainous regions, especially in regions with near-freezing winter temperatures is needed to better assess the impact of combined climate-vegetation-soil changes. Mountain water resource systems that are vulnerable to warming and land cover changes can be identified using the modeling strategy presented here. Future vegetation and soil changes need to be considered, in addition to a changing climate, to reduce the uncertainties regarding changing mountain hydrology.

Data availability. Long-term datasets and descriptions of the variables for each basin were published by Reba et al. (2011), Fang et al. (2019), and Rasouli et al. $(2018,2019 b)$.

Author contributions. All three coauthors contributed to the research design and writing the paper. KR developed the models for Wolf Creek and Marmot Creek. JWP managed and supervised the research. PHW helped with statistical analysis.
Competing interests. The authors declare that they have no conflict of interest.

Special issue statement. This article is part of the special issue "Understanding and predicting Earth system and hydrological change in cold regions". It is not associated with a conference.

Acknowledgements. We thank Danny Marks of the United States Department of Agriculture and the late Rick Janowicz of Yukon Environment, who had a long-term commitment to operating and providing the data for Reynolds Mountain and the Wolf Creek Research Basin, respectively. The research funding sources include the Canada Research Chairs program, the Natural Sciences and Engineering Research Council of Canada through Discovery Grants, the Alexander Graham Bell Canada Graduate Scholarship-Doctoral Program and Postdoctoral Fellowships, and the Changing Cold Regions Network. We thank Xing Fang for help with the modeling of Marmot Creek. The discussions and comments of Andrew Ireson and Lawrence Martz on an earlier draft of this paper are also appreciated, as are the helpful comments and suggestions of the two anonymous reviewers.

Financial support. This research has been supported by the Natural Sciences and Engineering Research Council of Canada (grant nos. PDF 487795-2016 and CGSD3 - 459225-2014).

Review statement. This paper was edited by Sean Carey and reviewed by two anonymous referees.

\section{References}

Abdi, H., and Williams, L. J.: Tukey's honestly significant difference (HSD) test, in: Encyclopedia of Research Design, edited by: Salkind, N., Sage, Thousand Oaks, CA, USA, 1-5, 2010.

Alberta Natural Regions Committee: Natural Regions and Subregions of Alberta, compiled by: Downing, D. J. and Petapiece, W. W., Government of Alberta Publication Number T/852, Edmonton, Alberta, Canada, 254 pp., 2006.

Bales, R. C., Hopmans, J. W., O'Geen, A. T., Meadows, M., Hartsough, P. C., Kirchner, P., Hunsaker, C. T., and Beaudette, D.: Soil moisture response to snowmelt and rainfall in a Sierra Nevada mixed-conifer forest, Vadose Zone J., 10, 786-799, 2011.

Beniston, M.: Climatic change in mountain regions: a review of possible impacts, in Climate variability and change in high elevation regions: past, present \& future, 5-31, Springer, Dordrecht, the Netherlands, https://doi.org/10.1007/978-94-015-1252-7_2, 2003.

Bennett, K. E., Werner, A. T., and Schnorbus, M.: Uncertainties in hydrologic and climate change impact analyses in headwater basins of British Columbia, J. Climate, 25, 5711-5730, 2012. 
Billings, W. D. and Bliss, L.: An alpine snowbank environment and its effects on vegetation, plant development, and productivity, Ecology, 40, 388-397, 1959.

Bjorkman, A. D., Myers-Smith, I. H., Elmendorf, S. C., Normand, S., Rüger, N., Beck, P. S., Blach-Overgaard, A., Blok, D., Cornelissen, J. H. C., Forbes, B. C., Georges, D., Goetz, S. J., Guay, K. C., Henry, G. H. R., HilleRisLambers, J., Hollister, R. D., Karger, D. N., Kattge, J., Manning, P., Prevéy, J. S., Rixen, C., Schaepman-Strub, G., Thomas, H. J. D., Vellend, M., Wilmking, M., Wipf, S., Carbognani, M., Hermanutz, L., Lévesque, E., Molau, U., Petraglia, A., Soudzilovskaia, N. A., Spasojevic, M. J., Tomaselli, M., Vowles, T., Alatalo, J. M., Alexander, H. D., Anadon-Rosell, A., Angers-Blondin,S., Beest, M., Berner, L., Björk,R. G., Buchwal, A., Buras, A., Christie, K., Cooper, E. J., Dullinger, S. Elberling, B., Eskelinen, A., Frei, E. R., Grau, O., Grogan, P., Hallinger, M., Harper, K. A., Heijmans, M. M. P. D., Hudson, J., Hülber, K. Iturrate-Garcia, M., Iversen, C. M., Jaroszynska, F., Johnstone, J. F., Jørgensen, R. H., Kaarlejärvi, E., Klady, R., Kuleza, S., Kulonen, A., Lamarque, L. J., Lantz, T., Little, C. J., Speed, J. D. M., Michelsen, A., Milbau, A., NabeNielsen, J., Nielsen, S. S., Ninot, J. M., Oberbauer, S. F., Olofsson, J., Onipchenko, V. G., Rumpf, S. B., Semenchuk, P., Shetti, R., Collier, L. S., Street, L. E., Suding, K. N., Tape, K. D., Trant, A., Treier, U. A., Tremblay, J., Tremblay, M., Venn, S., Weijers, S., Zamin, T., Boulanger-Lapointe, N., Gould, W. A., Hik, D. S., Hofgaard, A., Jónsdóttir, I. S., Jorgenson, J., Klein, J., Magnusson, B., Tweedie, C., Wookey, P. A., Bahn, M., Blonder, B., van Bodegom, P. M., Bond-Lamberty, B., Campetella, G., Cerabolini, B. E. L., Chapin III, F. S., Cornwell, W. K., Craine, J., Dainese, M., de Vries, F. T., Díaz, S., Enquist, B. J., Green, W., Milla, R., Niinemets, Ü., Onoda, Y., Ordoñez, J. C., Ozinga, W. A., Penuelas, J., Poorter, H., Poschlod, P., Reich, P. B., Sandel, B., Schamp, B., Sheremetev, S., and Weiher, E.: Plant functional trait change across a warming tundra biome, Nature, 562, 57-62, https://doi.org/10.1038/s41586-018-0563-7, 2018.

Bonan, G. B.: Forests and climate change: forcings, feedbacks, and the climate benefits of forests, Science, 320, 1444-1449, 2008.

Bosch, J. M. and Hewlett, J.: A review of catchment experiments to determine the effect of vegetation changes on water yield and evapotranspiration, J. Hydrol., 55, 3-23, 1982.

Brown, A. E., Zhang, L., McMahon, T. A., Western, A. W., and Vertessy, R. A.: A review of paired catchment studies for determining changes in water yield resulting from alterations in vegetation, J. Hydrol., 310, 28-61, 2005.

Callaghan, T. V., Johansson, M., Brown, R. D., Groisman, P. Y., Labba, N., Radionov, V., Bradley, R. S., Blangy, S., Bulygina, O. N., Christensen, T. R., Coleman, J. E., Essery, R. L. H., Forbes, B. C., Forchhammer, M. C., Golubev, V. N., Honrath, R. E., Juday, G. P., Mehcherskaya, A. V., Phoenix, G. K., Pomeroy, J., Rautio, A., Robinson, D. A., Schmidt, N. M., Serreze, M. C., Shevchenko, V. P., Shiklomanov, A. I., Shmakin, A. B., Sköld, P., Sturm, M., Woo, M.-K., and Wood, E. F.: Multiple effects of changes in Arctic snow cover, Ambio, 40, 32-45, 2011.

Crocker, R. L. and Major, J.: Soil development in relation to vegetation and surface age at Glacier Bay, Alaska, J. Ecol., 43, 427448, https://doi.org/10.2307/2257005, 1955.

Dale, V. H. and Franklin, J. F.: Potential effects of climate change on stand development in the Pacific Northwest, Can. J. Forest Res., 19, 1581-1590, 1989.
DeBano, L. F.: The effect of fire on soil properties, 10-12 April 1990, Boise, Idaho Gen. Tech. Rep. INT-280. Ogden, Utah, USA, 151-156, 1991.

DeFries, R. and Eshleman, K. N.: Land-use change and hydrologic processes: A major focus for the future, Hydrol. Process., 18, 2183-2186, 2004.

Ellis, C. R., Pomeroy, J. W., Brown, T., and MacDonald, J.: Simulation of snow accumulation and melt in needleleaf forest environments, Hydrol. Earth Syst. Sci., 14, 925-940, https://doi.org/10.5194/hess-14-925-2010, 2010.

Fang, X., Pomeroy, J. W., Ellis, C. R., MacDonald, M. K., DeBeer, C. M., and Brown, T.: Multi-variable evaluation of hydrological model predictions for a headwater basin in the Canadian Rocky Mountains, Hydrol. Earth Syst. Sci., 17, 1635-1659, https://doi.org/10.5194/hess-17-1635-2013, 2013.

Fang, X., Pomeroy, J. W., DeBeer, C. M., Harder, P., and Siemens, E.: Hydrometeorological data from Marmot Creek Research Basin, Canadian Rockies, Earth Syst. Sci. Data, 11, 455-471, https://doi.org/10.5194/essd-11-455-2019, 2019.

Flerchinger, G. N., Reba, M. L., and Marks, D.: Measurement of surface energy fluxes from two rangeland sites and comparison with a multilayer canopy model, J. Hydrometeorol., 13, 10381051, 2012.

Fowler, H., Blenkinsop, S., and Tebaldi, C.: Linking climate change modelling to impacts studies: recent advances in downscaling techniques for hydrological modelling, Int. J. Climatol., 27, 1547-1578, 2007.

Francis, S., Smith, S., and Janowicz, R.: Data integration and ecological zonation of Wolf Creek watershed, in Wolf Creek Research Basin-Hydrology, Ecology, Environment-Proceedings of a workshop held in Whitehorse, Yukon, edited by: Pomeroy, J. W. and Granger R. J., 93-100, Citeseer, Saskatoon, Canada, 1998.

Gelfan, A. N., Pomeroy, J. W., and Kuchment, L. S.: Modeling forest cover influences on snow accumulation, sublimation, and melt, J. Hydrometeorol., 5, 785-803, 2004.

Goodison, B., Louie, P., and Yang, D.: The WMO solid precipitation measurement intercomparison, World Meteorological Organization, Geneva, Switzerland, 65-70, 1998.

Gutmann, E., Barstad, I., Clark, M., Arnold, J., and Rasmussen, R.: The Intermediate Complexity Atmospheric Research Model (ICAR), J. Hydrometeorol., 17, 957-973, 2016.

Hallinger, M., Manthey, M., and Wilmking, M.: Establishing a missing link: warm summers and winter snow cover promote shrub expansion into alpine tundra in Scandinavia, New Phytol., 186, 890-899, 2010.

Halofsky, J. E., Peterson, D. L., and Prendeville, H. R.: Assessing vulnerabilities and adapting to climate change in northwestern US forests, Climatic Change, 146, 89-102, 2018.

Hansell, R., Chant, D., and Weintraub, J.: Changes in the northern limit of spruce at Dubawnt Lake, Northwest Territories, Arctic, 24, 233-234, 1971.

Hay, L. E., Wilby, R. L., and Leavesley, G. H.: A comparison of delta change and downscaled GCM scenarios for three mountainous basins in the United States, J. Am. Water Resour. Assoc., 36, 387-397, 2000.

Hijmans, R. J., Cameron, S. E., Parra, J. L., Jones, P. G., and Jarvis, A.: Very high resolution interpolated climate surfaces for global land areas, Int. J. Climatol., 25, 1965-1978, 2005. 
Innes, J.: High-altitude and high-latitude tree growth in relation to past, present and future global climate change, Holocene, 1, 168173, 1991

Kay, A., Davies, H., Bell, V., and Jones, R.: Comparison of uncertainty sources for climate change impacts: flood frequency in England, Climatic Change, 92, 41-63, 2009.

Keller, F., Goyette, S., and Beniston, M.: Sensitivity analysis of snow cover to climate change scenarios and their impact on plant habitats in alpine terrain, Climatic Change, 72, 299-319, 2005.

Kirby, C. and Ogilvie, R.: The forests of Marmot Creek watershed research basin, Canadian Forestry Service, Queen's Press, Calgary, Alberta, Canada, 47-1259, 1-37, 1969.

Köppen, W.: Das geographische System der Klimate, in: Handbuch der klimatologie, edited by: Köppen, W., and Geiger, R., Band 1, Teil C, Gebrüder Borntraeger, Berlin, Germany, 44 pp., 1936.

Krogh, S. A. and Pomeroy, J. W.: Recent changes to the hydrological cycle of an Arctic basin at the tundra-taiga transition, Hydrol. Earth Syst. Sci., 22, 3993-4014, https://doi.org/10.5194/hess-223993-2018, 2018.

Krogh, S. A. and Pomeroy, J. W.: Impact of future climate and vegetation on the hydrology of an Arctic headwater basin at the tundra-taiga transition, J. Hydrometeorol., 20, 197-215, 2019.

Lamprecht, A., Semenchuk, P. R., Steinbauer, K., Winkler, M., and Pauli, H.: Climate change leads to accelerated transformation of high-elevation vegetation in the central Alps, New Phytol., 220, 447-459, 2018.

Lawrence, D. M. and Swenson, S. C.: Permafrost response to increasing Arctic shrub abundance depends on the relative influence of shrubs on local soil cooling versus largescale climate warming, Environ. Res. Lett., 6, 045504, https://doi.org/10.1088/1748-9326/6/4/045504, 2011.

Lewkowicz, A. G. and Ednie, M.: Probability mapping of mountain permafrost using the BTS method, Wolf Creek, Yukon Territory, Canada, Permafrost Periglac., 15, 67-80, 2004.

Link, T. E., Flerchinger, G. N., Unsworth, M., and Marks, D.: Simulation of water and energy fluxes in an old-growth seasonal temperate rain forest using the simultaneous heat and water (SHAW) model, J. Hydrometeorol., 5, 443-457, 2004.

Liston, G. E., Mcfadden, J. P., Sturm, M., and Pielke, R. A.: Modelled changes in arctic tundra snow, energy and moisture fluxes due to increased shrubs, Glob. Change Biol., 8, 17-32, 2002.

Lundquist, J. D., Dickerson-Lange, S. E., Lutz, J. A., and Cristea, N. C.: Lower forest density enhances snow retention in regions with warmer winters: A global framework developed from plot-scale observations and modeling, Water Resour. Res., 49, 6356-6370, 2013.

MacDonald, M. K., Pomeroy, J. W., and Pietroniro, A.: Parameterizing redistribution and sublimation of blowing snow for hydrological models: tests in a mountainous subarctic catchment, Hydrol. Process., 23, 2570-2583, 2009.

MacDonald, M. K., Pomeroy, J. W., and Pietroniro, A.: On the importance of sublimation to an alpine snow mass balance in the Canadian Rocky Mountains, Hydrol. Earth Syst. Sci., 14, 14011415, https://doi.org/10.5194/hess-14-1401-2010, 2010.

Macias-Fauria, M. and Johnson, E. A.: Large-scale climatic patterns and area affected by mountain pine beetle in British Columbia, Canada, J. Geophys. Res.-Biogeo., 114, G01012, https://doi.org/10.1029/2008JG000760, 2009.
Mann, D. H., Scott Rupp, T., Olson, M. A., and Duffy, P. A.: Is Alaska's boreal forest now crossing a major ecological threshold?, Arct. Antarct. Alp. Res., 44, 319-331, 2012.

Mann, H. B. and Whitney, D. R.: On a test of whether one of two random variables is stochastically larger than the other, Ann. Math. Stat., 18, 50-60, 1947.

Martin, A. C., Jeffers, E. S., Petrokofsky, G., Myers-Smith, I., and Macias-Fauria M.: Shrub growth and expansion in the Arctic tundra: an assessment of controlling factors using an evidence-based approach, Environ. Res. Lett., 12, 085007, https://doi.org/10.1088/1748-9326/aa7989, 2017.

Massey Jr., F. J.: The Kolmogorov-Smirnov test for goodness of fit, J. Am. Stat. Assoc., 46, 68-78, 1951.

Mearns, L., Gutowski, W., Jones, R., Leung, L., McGinnis, S., Nunes, A., and Qian, Y.: The North American regional climate change assessment program dataset, National Center for Atmospheric Research Earth System Grid Data Portal, Boulder, CO, https://doi.org/10.5065/D6RN35ST, 2007.

Musselman, K. N., Clark, M. P., Liu, C., Ikeda, K., and Rasmussen, R.: Slower snowmelt in a warmer world, Nat. Clim. Change, 7, 214-220, https://doi.org/10.1038/NCLIMATE3225, 2017.

Myers-Smith, I. H. and Hik, D. S.: Climate warming as a driver of tundra shrubline advance, J. Ecol., 106, 547-560, 2018.

Neilson, R. P. and Marks, D.: A global perspective of regional vegetation and hydrologic sensitivities from climatic change, J. Veg. Sci., 5, 715-730, 1994.

Nijssen, B., O'donnell, G. M., Hamlet, A. F., and Lettenmaier, D. P.: Hydrologic sensitivity of global rivers to climate change, Climatic Change, 50, 143-175, 2001.

Osterkamp, T., Jorgenson, M., Schuur, E., Shur, Y., Kanevskiy, M., Vogel, J., and Tumskoy, V.: Physical and ecological changes associated with warming permafrost and thermokarst in interior Alaska, Permafrost Periglac., 20, 235-256, 2009.

Pielke, R. A.: Land use and climate change, Science, 310, 16251626, 2005.

Pomeroy, J. W. and Gray, D. M.: Sensitivity of snow relocation and sublimation to climate and surface vegetation, P. Int. Ass. Hydrol. Sci., 223, 213-226, 1994.

Pomeroy, J. W., Hedstrom, N., and Parviainen, J.: The snow mass balance of Wolf Creek, Yukon: effects of snow sublimation and redistribution, Wolf Creek Research Basin-Hydrology, Ecology, Environment-Proceedings of a workshop held in Whitehorse, Yukon, edited by: Pomeroy, J. W. and Granger R. J., Saskatoon, Canada, 15-30, 1999.

Pomeroy, J. W., Toth, B., Granger, R., Hedstrom, N., and Essery, R.: Variation in surface energetics during snowmelt in a subarctic mountain catchment, J. Hydrometeorol., 4, 702-719, 2003.

Pomeroy, J. W., Bewley, D., Essery, R., Hedstrom, N., Link, T., Granger, R., Sicart, J.-E., Ellis, C., and Janowicz, J.: Shrub tundra snowmelt, Hydrol. Process., 20, 923-941, 2006.

Pomeroy, J. W., Gray, D. M., Brown, T., Hedstrom, N., Quinton, W., Granger, R. J., and Carey, S.: The cold regions hydrological model: A platform for basing process representation and model structure on physical evidence, Hydrol. Process., 21, 2650-2667, https://doi.org/10.1002/hyp.6787, 2007.

Pomeroy, J. W., Fang, X., and Ellis, C.: Sensitivity of snowmelt hydrology in Marmot Creek, Alberta, to forest cover disturbance, Hydrol. Process., 26, 1891-1904, 2012. 
Pomeroy, J. W., Spence, C., and Whitfield, P. H.: Putting prediction in ungauged basins into practice, Canmore, Alberta, Canadian Water Resources Association, Ottawa, Canada, 1-12, 2013.

Pomeroy, J. W., Fang, X., and Rasouli, K.: Sensitivity of snow processes to warming in the Canadian Rockies, 72nd Eastern Snow Conference, 9-11 June 2015, Sherbrooke, Québec, Canada, 2233, 2015.

Rasouli, K.: Sensitivity analysis of mountain hydrology to changing climate, PhD Dissertation, University of Saskatchewan, Saskatoon, Canada, 251 pp., 2017.

Rasouli, K., Pomeroy, J. W., Janowicz, J. R., Carey, S. K., and Williams, T. J.: Hydrological sensitivity of a northern mountain basin to climate change, Hydrol. Process., 28, 4191-4208, 2014.

Rasouli, K., Pomeroy, J. W., and Marks, D. G.: Snowpack sensitivity to perturbed climate in a cool mid-latitude mountain catchment, Hydrol. Process., 29, 3925-3940, 2015.

Rasouli, K., Pomeroy, J., Janowicz, J. R., Williams, T., and Carey, S.: Hydrometeorological data collected at Wolf Creek Research Basin, Yukon Territory, Canada over 1993-2014, Federated Research Data Repository, https://doi.org/10.20383/101.0113, 2018.

Rasouli, K., Pomeroy, J. W., and Whitfield, P. H.: Hydrological responses of headwater basins to perturbed climate in North American Cordillera, J. Hydrometeorol., 20, 863-882, https://doi.org/10.1175/JHM-D-18-0166.1, 2019a.

Rasouli, K., Pomeroy, J. W., Janowicz, J. R., Williams, T. J., and Carey, S. K.: A long-term hydrometeorological dataset (19932014) of a northern mountain basin: Wolf Creek Research Basin, Yukon Territory, Canada, Earth Syst. Sci. Data, 11, 89-100, https://doi.org/10.5194/essd-11-89-2019, 2019b.

Rawlins, M. A., Steele, M., Serreze, M. C., Vörösmarty, C. J., Ermold, W., Lammers, R. B., McDonald, K. C., Pavelsky, T. M., Shiklomanov, A., and Zhang, J.: Tracing freshwater anomalies through the air-land-ocean system: A case study from the Mackenzie river basin and the Beaufort Gyre, Atmos.-Ocean, 47, 79-97, 2009.

Reba, M. L., Marks, D., Seyfried, M., Winstral, A., Kumar, M., and Flerchinger, G.: A long-term data set for hydrologic modeling in a snow-dominated mountain catchment, Water Resour. Res., 47, W07702, https://doi.org/10.1029/2010WR010030, 2011.

Reiners, W., Bouwman, A., Parsons, W., and Keller, M.: Tropical rain forest conversion to pasture: changes in vegetation and soil properties, Ecol. Appl., 4, 363-377, 1994.

Rodriguez-Iturbe, I.: Ecohydrology: A hydrologic perspective of climate-soil-vegetation dynamics, Water Resour. Res., 36, 3-9, 2000.

Schneider, R. R.: Alberta's natural subregions under a changing climate: past, present, and future, Alberta Biodiversity Monitoring Institute, Edmonton, Canada, 86 pp., 2013.

Schneider, R. R., Hamann, A., Farr, D., Wang, X., and Boutin, S.: Potential effects of climate change on ecosystem distribution in Alberta, Can. J. Forest Res., 39, 1001-1010, 2009.

Seyfried, M., Grant, L., Marks, D., Winstral, A., and McNamara, J.: Simulated soil water storage effects on streamflow generation in a mountainous snowmelt environment, Idaho, USA, Hydrol. Process., 23, 858-873, 2009.
Smith, C. D.: April. The relationship between snowfall catch efficiency and wind speed for the Geonor T-200B precipitation gauge utilizing various wind shield configurations, in: Proc. 77th Western Snow Conference, 20-23 April 2009, Canmore, Alberta, Canada, 115-121, 2009.

Stanton, M., Rejmanek, M., and Galen C.: Changes in vegetation and soil fertility along a predictable snowmelt gradient in the Mosquito Range, Colorado, USA, Arctic Alp. Res., 26, 364-374, 1994.

Stow, D. A., Hope, A., McGuire, D., Verbyla, D., Gamon, J., Huemmrich, F., Houston, S., Racine, C., Sturm, M., Tape, K., Hinzman, L., Yoshikawa, K., Tweedie, C., Noyle, B., Silapaswan, C., Douglas, D., Griffith, B., Jia, G., Epstein, H., Walker, D., Daeschner, S., Petersen, A., Zhou, L., and Myneni, R.: Remote sensing of vegetation and land-cover change in Arctic Tundra Ecosystems, Remote Sens. Environ., 89, 281-308, 2004.

Sturm, M., Schimel, J., Michaelson, G., Welker, J. M., Oberbauer, S. F., Liston, G. E., Fahnestock, J., and Romanovsky, V. E.: Winter biological processes could help convert arctic tundra to shrubland, Bioscience, 55, 17-26, 2005.

Sunyer, M., Madsen, H., and Ang, P.: A comparison of different regional climate models and statistical downscaling methods for extreme rainfall estimation under climate change, Atmos. Res., 103, 119-128, 2012.

Tape, K., Sturm, M., and Racine, C.: The evidence for shrub expansion in northern Alaska and the Pan-Arctic, Glob. Change Biol., 12, 686-702, 2006.

Tukey, J. W.: The philosophy of multiple comparisons, Stat. Sci., 6, 100-116, 1991.

Walker, D., Halfpenny, J. C., Walker, M. D., and Wessman, C. A.: Long-term studies of snow-vegetation interactions, BioScience, 43, 287-301, 1993.

Walvoord, M. A. and Kurylyk, B. L.: Hydrologic impacts of thawing permafrost - A review, Vadose Zone J., 15, 1-20, https://doi.org/10.2136/vzj2016.01.0010, 2016.

Wilcoxon, F.: Individual comparisons by ranking methods, Biometrics Bull., 1, 80-83, 1945.

Williams, T. J., Pomeroy, J. W., Janowicz, J. R., Carey, S. K., Rasouli, K., and Quinton, W. L.: A radiative-conductive-convective approach to calculate thaw season ground surface temperatures for modelling frost table dynamics, Hydrol. Process., 29, 3954 3965, 2015.

Winstral, A. and Marks, D.: Long-term snow distribution observations in a mountain catchment: Assessing variability, time stability, and the representativeness of an index site, Water Resour. Res., 50, 293-305, 2014.

Zhang, Y., Carey, S. K., and Quinton, W. L.: Evaluation of the algorithms and parameterizations for ground thawing and freezing simulation in permafrost regions, J. Geophys. Res.-Atmos., 113, D17116, https://doi.org/10.1029/2007JD009343, 2008. 